$$
\begin{aligned}
& \text { احاق التكامل النقدي: دراسه وي تجربه مجلس التعاون } \\
& \text { لدول الخليج العربيه } \\
& \text { د.عبد الله فاضل الحيالي } \\
& \text { مدرس·- قسم الدر اسات الاقتصادية و الاجتماعية/ } \\
& \text { مركز الدراسات الإقليمية.- جامعة الموصل }
\end{aligned}
$$

\title{
مستخلص البحت
}

إن تتـابه الاوتصادات الخليجيه العربيه بتيويا, وتتـــاعم سياســاتها الاوتصــاديه

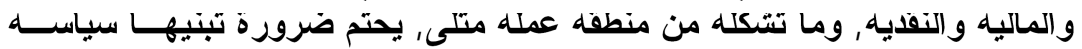
اسعار صرف تابته بين عملاتها, كما ان إنتشاء عمله موحدة لها ما يســوعها مسن ونس

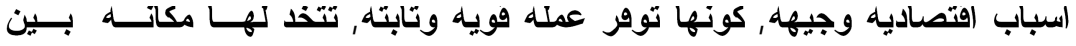

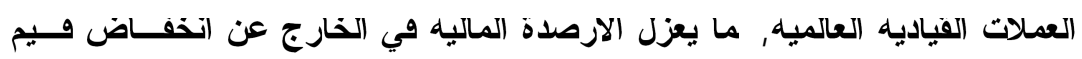

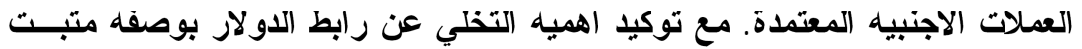
مشترك للعمله الموحدة, وإستبداله بسله من العملات الفائمه على روم فياسي مرجح

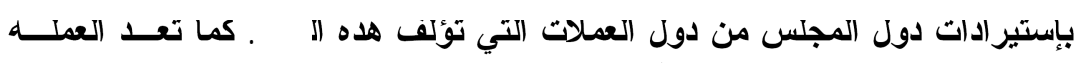

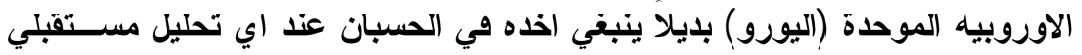
للترتيبات المناسبه لنظام سعر صرف العمله الموحدة.

(المقدمهة

يبين تحليل الاقتصاد الدولي ان مطلع ستينات القرن العشرين قد شـــــ و لادة نظرية النكامل الاقتصادي, وكان ر ائدها "بيلا باللسا" في مؤلفه دائع

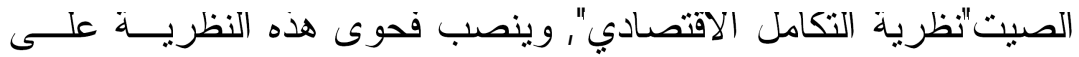
سعي مجموعة من الدول التي غالبا ما تكون ضمن نطاق إقليمي محـدَدّ,

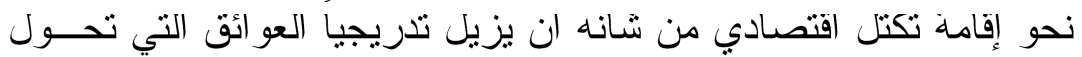
دون الحركة الحرة لعو امل الإنتاج و السلّع و الخدمات بما بؤدي ذلك الــى 
حصول تساوِ نسبي في التكاليف والاسعار وتوزيــع الـــدخل و الرفاهيـــة الاقتصادية بين الدول الاعضاء في التجمع الإقليمي, وصو لاً الــى قيــام

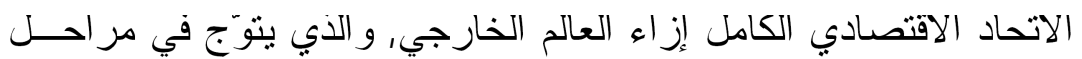
متقدمة بالوحدة السياسية الناجزة. ويتمثل التكامل الاقتصادي بحسب منظور "بيلا بالاسا" بكونه "عملي ـة

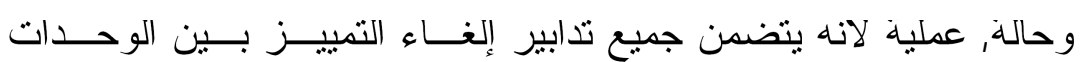

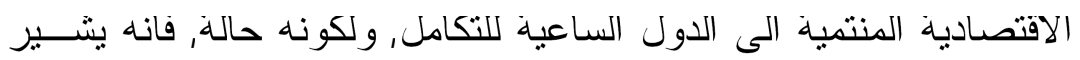
الى إلغاء مختلف صور التمبيز بين الاقتصادات المحليه"ا(1).

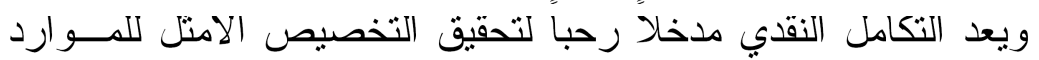
الاقتصادية للدول المنضوية تحت لو ائه. إد يجري تكامل اسواق عو امـلـل

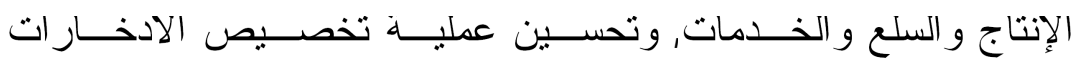
و الاستثمار ات في ظل السوق الموسعة بفعل إز الة القيود على حركة العمل ولى

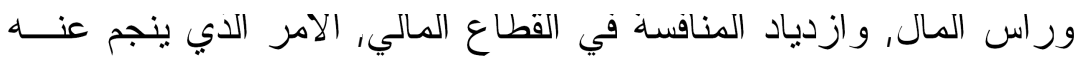

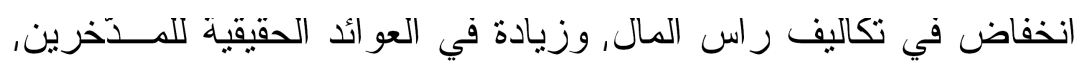

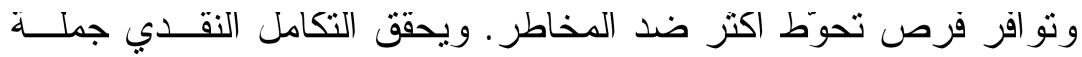
منافع تترتب على إطلاق العملة الموحدة لعل في مقدمتها استخدام معيــار

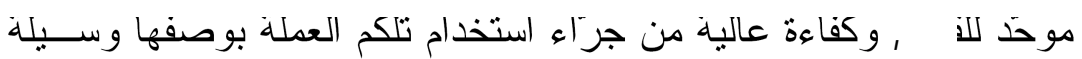

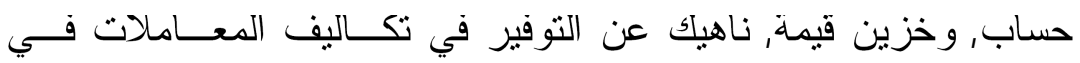

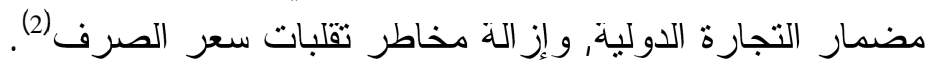
و ونذ بو اكير تاسيس مجلس التعاون لدول الخليج العربية, ياتي الاهتمام

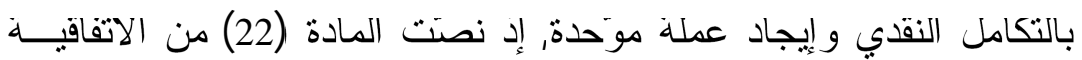

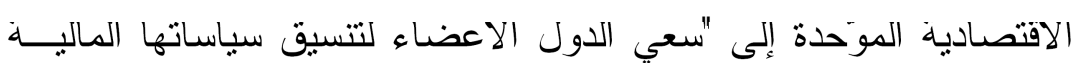

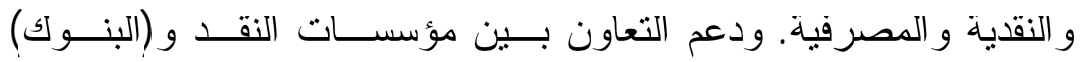




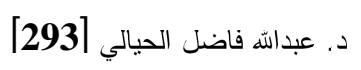

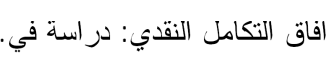

المركزية لديها, ما في دلك إنتاء عملة موَحدة لدعم تكاملها الاقتصـادي

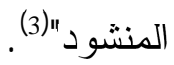

إن إقامة التكامل النقدي, وإطلاق العملة الموّحدة بين دول المجلس, يعد المبا

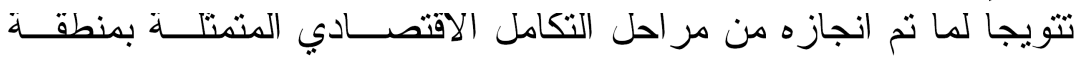

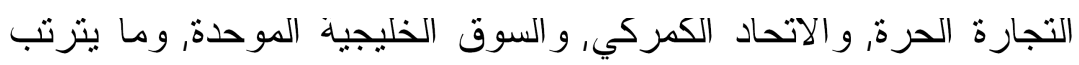

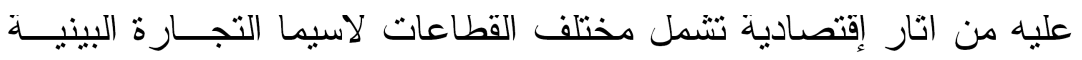

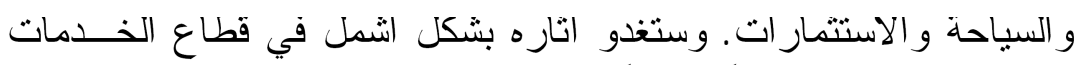

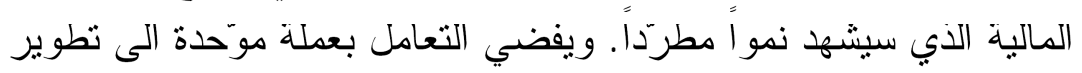

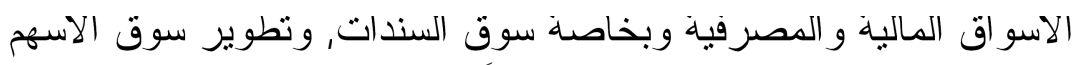

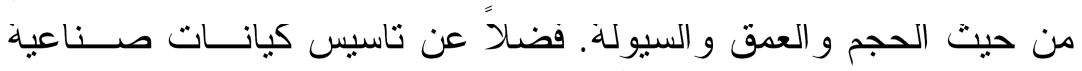

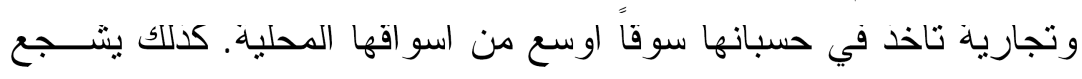

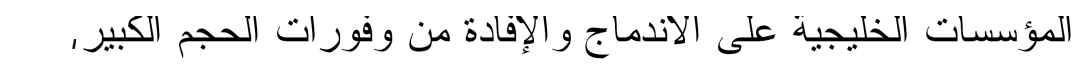

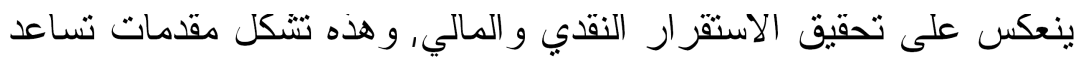

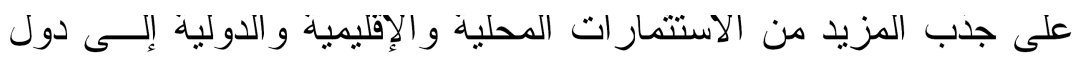

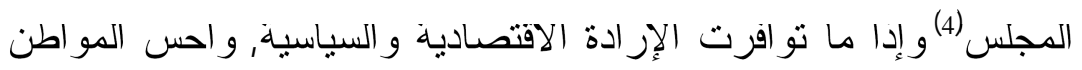

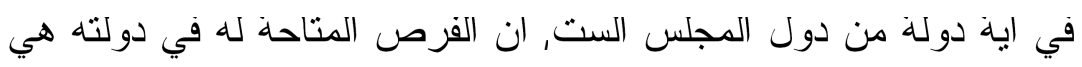

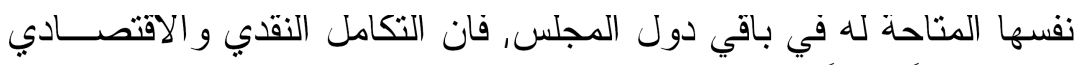

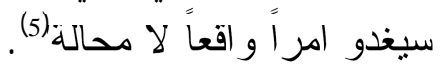

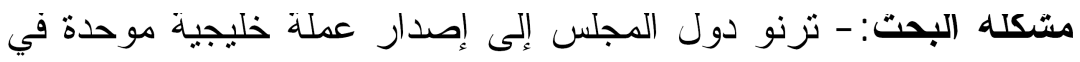

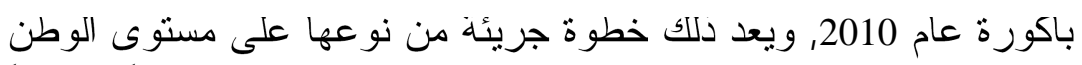

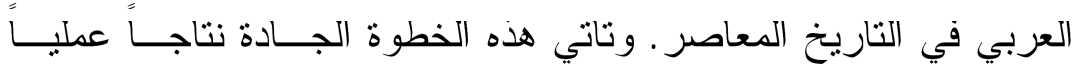

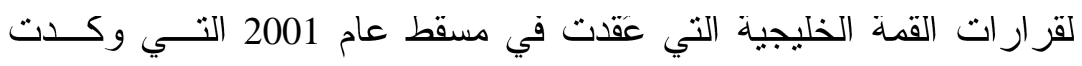

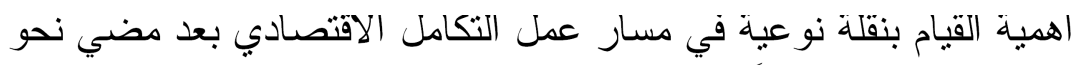
اكتر من عشرين عاماً (عند انعقاد قمة مسقط) على إنشاء مجلس التعاون, 
وتو اضع الانجاز ات الاقتصادية مقارنة بما كان مامو لا, ناهيك عن بروز

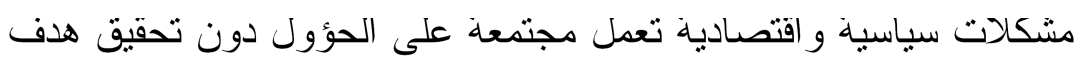
إطلاق العملة الموَحدة في مو عدها المقرر في مطلع عام 2010.

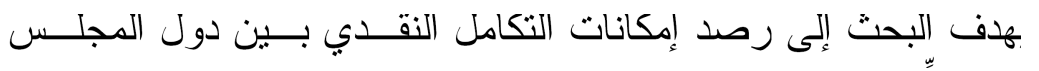

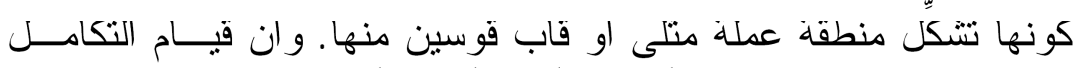

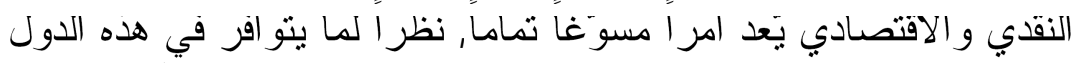

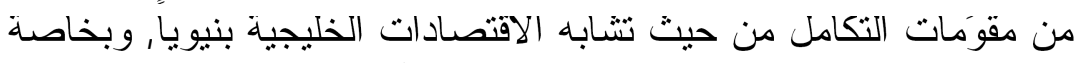

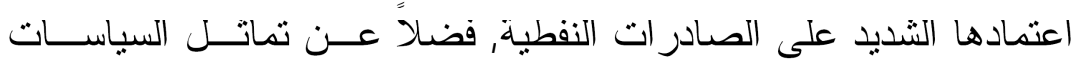

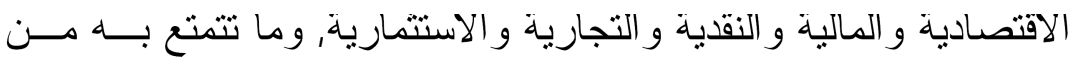

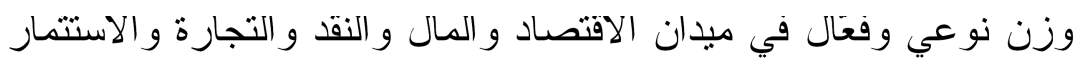
على صعيد الاقتصاد الدولي.

ياتي اختيار تجربة مجلس التعاون لدول الخلــيج العربيــة بوصــفها

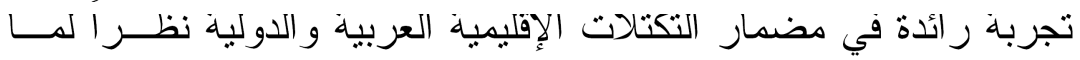

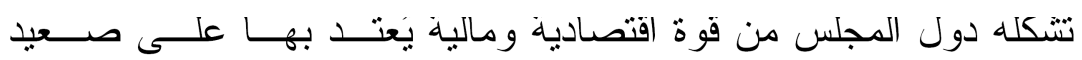

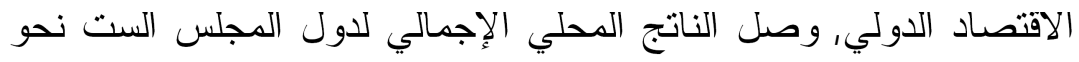

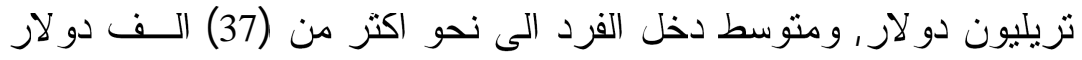

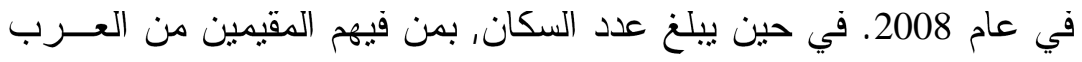

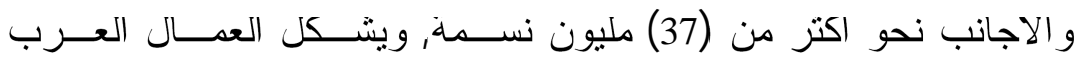

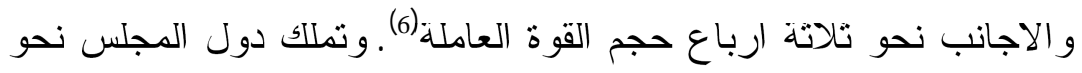
(45\%) من احتياطي النفط العالمي, ونحو (17\%) من احتيــاطي الغـــاز

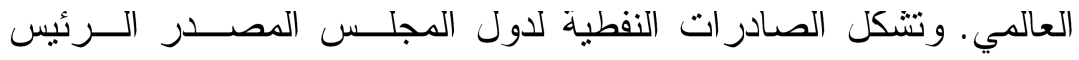


للإِير ادات الحكوميذ،, إد بلغت نحو (76\%) موز عة على (92\%) من تلكــ

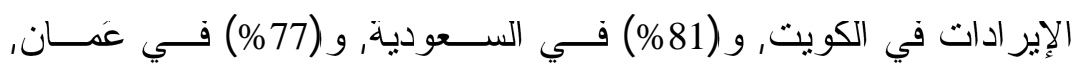

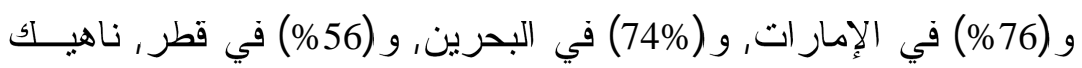

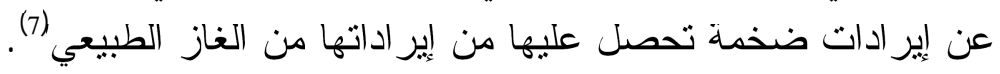

\section{ورضيه (لبحث}

يتطلب التكامل النقدي, وما يترتب عليه من إصدار عملة موَحدة تتسيقا تاماً في السياسات النقدية و المالية ربما يكفل تحقيق تناغم عال في معايير

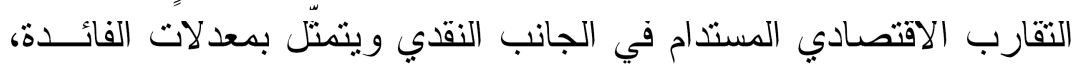

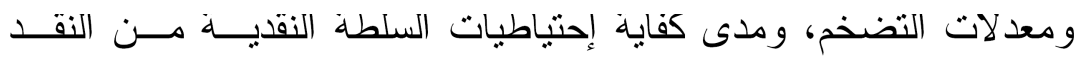

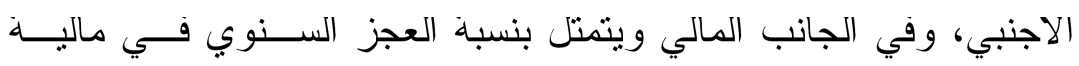

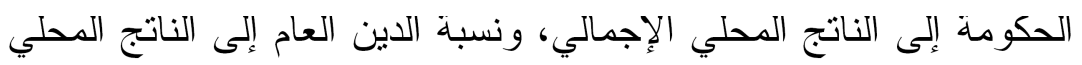
الإجمالي بين اعضاء مجلس التعاون لدول الخليج العربية.

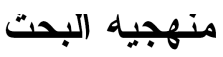

يتبع البحث المنهج الوصفي و التحليلي. وبغية الوصول إلى ذلك جرى

$$
\text { تقسيم البحث إلى اربعة مباحث. }
$$

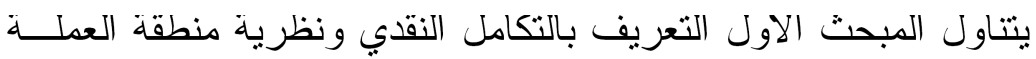

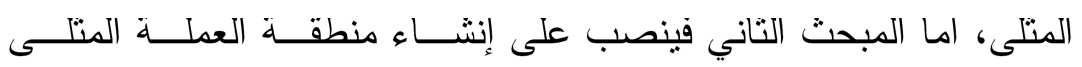

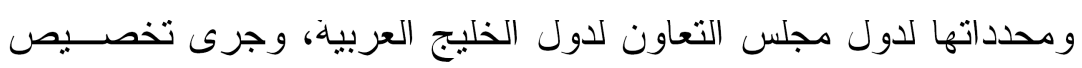

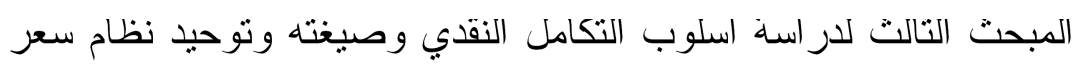

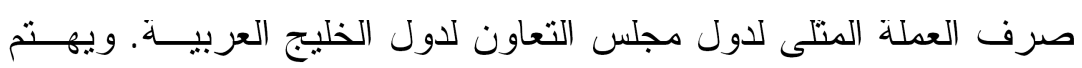

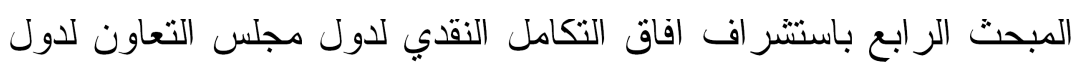

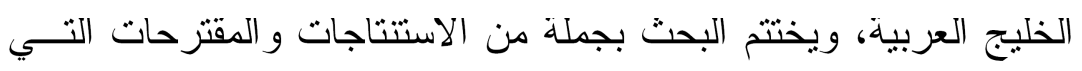
تمكن الباحث من الخلوص ولتئه إليها. 
المبحث الاول: التعريف بالتكامل التقدي ونظريه منطقه العمله المتلى اولا: حول مفهومي التكامل الاقتصادي و التكامل النقدي و العلاقة بينما:

لعل في قراءة المفاهيم النظرية للنكامل الاقتصادي و التكامل النقدي ما

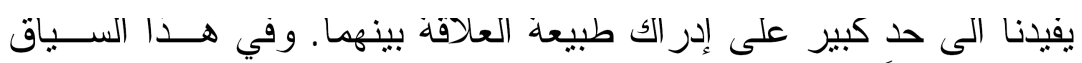

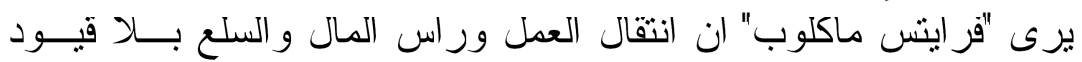

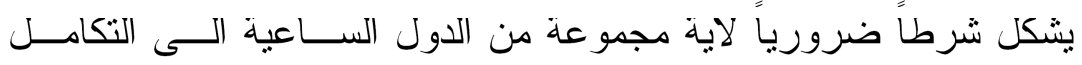
الاقتصادي, بيد ان حرية السفر و الهجرة, وحرية حركة رؤوس الأمو اله وحرية التجارة بهذا المعنى, لبست شرطاً كافياً لتحقيق التكامل الاقتصادي لئه

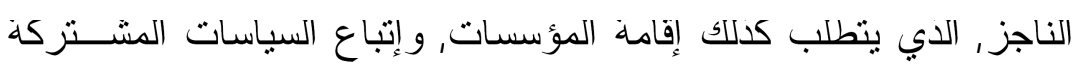

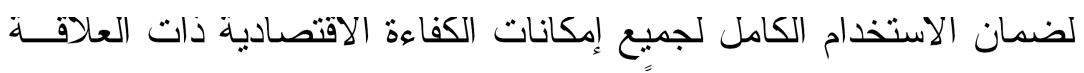

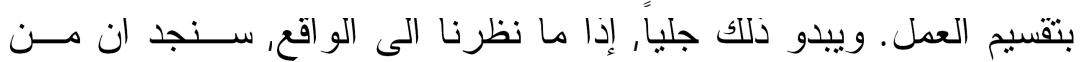

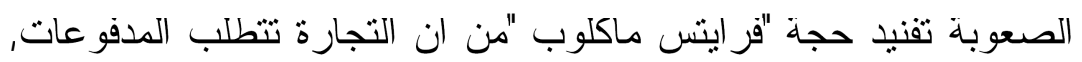
و ان حركة رؤوس الامو ال تتطلب نهيئة الفرص للحصول على على الاجــور

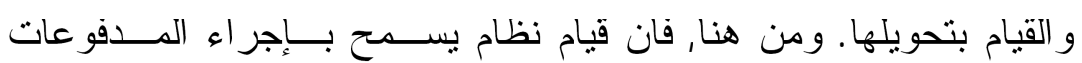

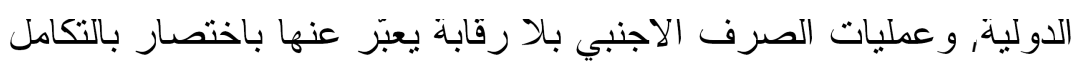

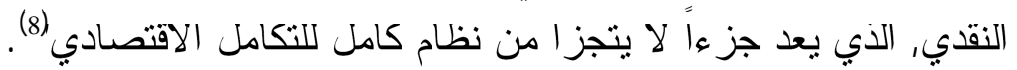

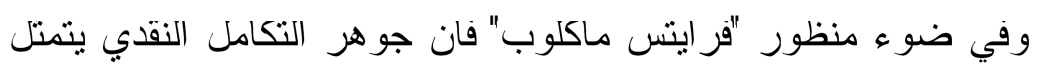

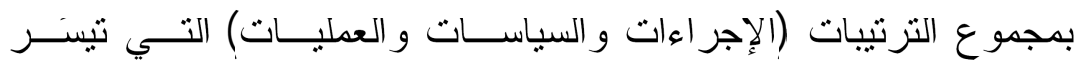

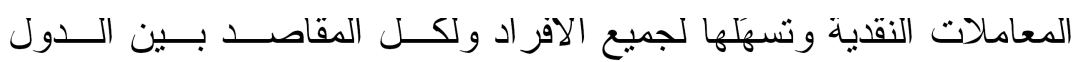

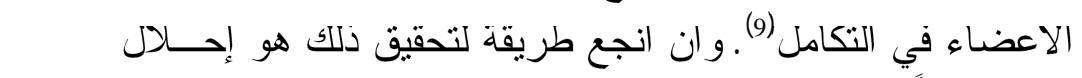

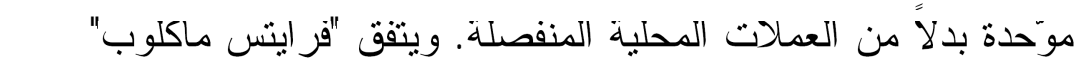

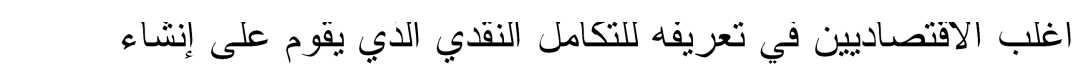

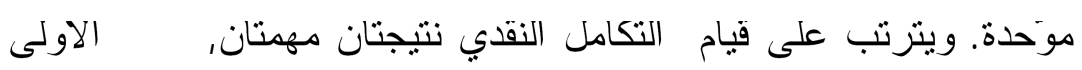


في انه ما دامت إدارة اية عملة لابد وان يكــون طــرف مـــا مســؤو لا

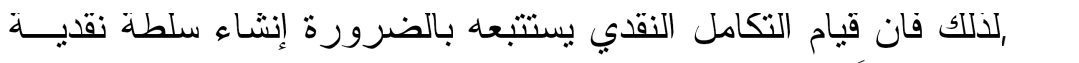
مركزية،, و عادةً ما تتخذ شكل مصرف مركزي. اما النتيجة الثانية,فتتمل

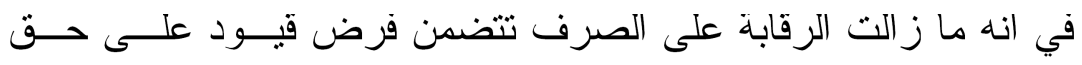

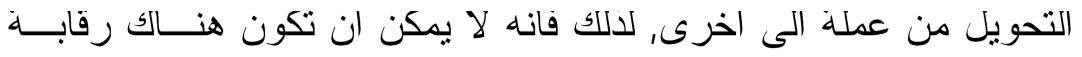
على الصرف في داخل منطقة موَحدة نقدياً (10). ويترتب على هاتين النتيجتين مضامين سياسية عميقة، إد يتم التتـــازل عن وظيفتان مهمتان من وظائف الحكومة المستقلة هما السياسة النقديـة.

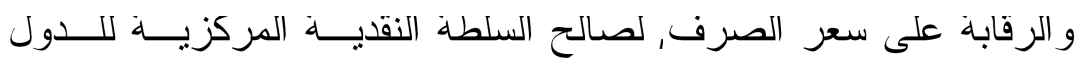

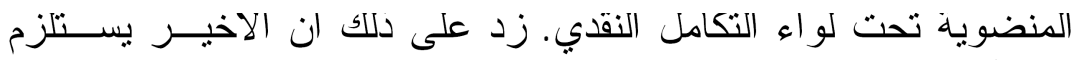

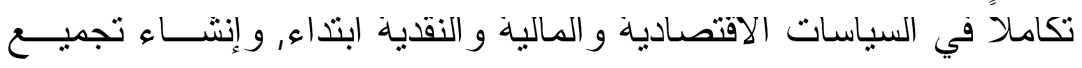

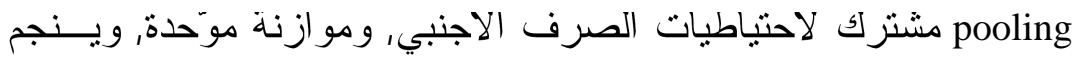

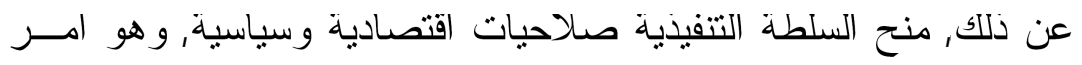

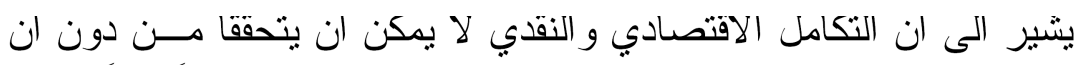

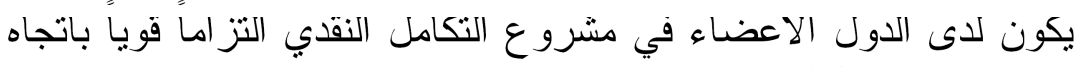
الوحدة السباسبة(11). ولقد اهتمت در اسـات عدة دارت حول التكامل النقدي بالحــديث عــن

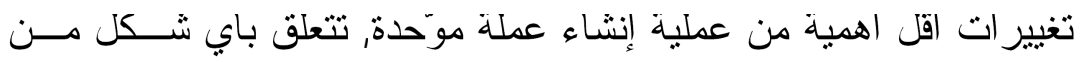

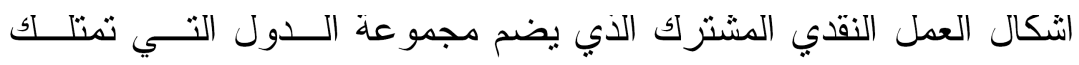

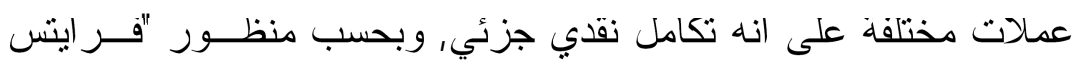

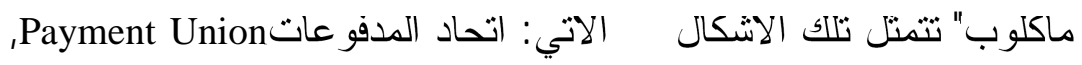
وتتسـيق اســعار الصــرف Exchange Rate Coordination, وتجميـع فئع الاحتياطي Reserve Pooling, و تكامل سوق راس المال Capital Market Integration 
Common Policies Toward External تجاه التدققات الخارجية لر اس المال Capital Flows و التتسيق النقدي Monetary Coordination

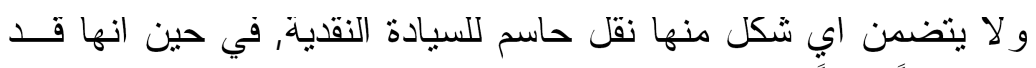

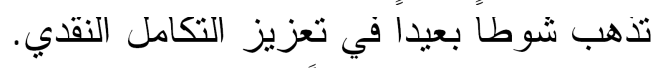
من حاصل ما تقدم انفا, يتبين لنا ان الحد الادنى لمفهوم التكامل النقدي يتمثل بغياب القيود على جميع المعاملات النقدية قصيرة وطويلة الامد.

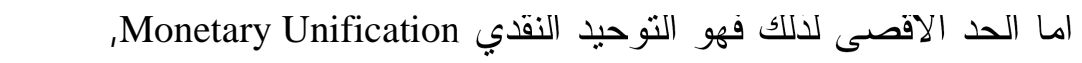
تبني عملة موَحدة (متماثلة) Uniform Currency, وما بين هدين الحدَين يمكن تتسيق السياسات النقدية المحلية(13). وحول العلاقة بين مفهومي التكامل الاقتصادي و التكامل النقدي, يو اجها

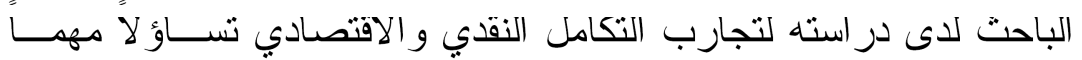

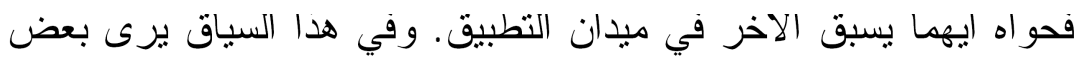
الاقتصاديين انه يصعب تحقيق تكامل اقتصادي كامل من دون قيام تكامل

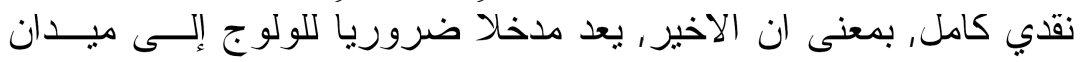

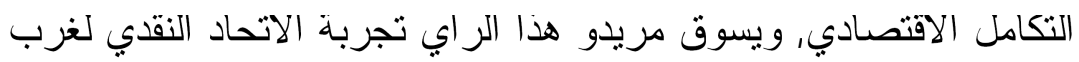

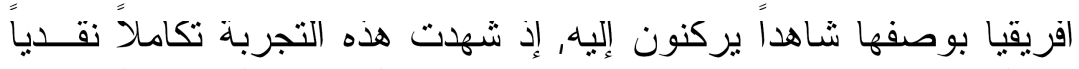

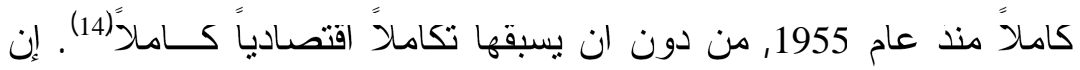

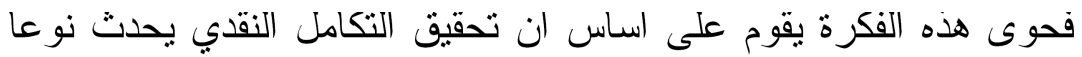

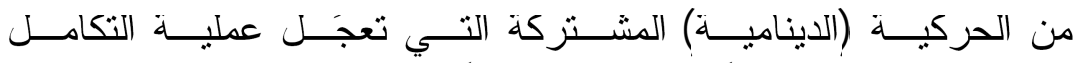
الاقتصادي"15). و ارتباطاً بما تقدم دكره تو اً, فانه لا جدوى من قيام التكامل

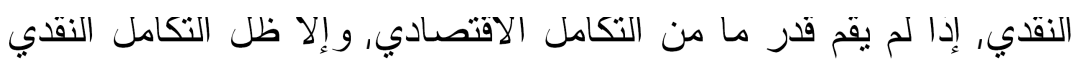

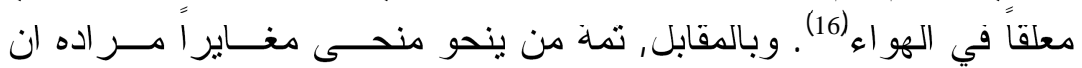

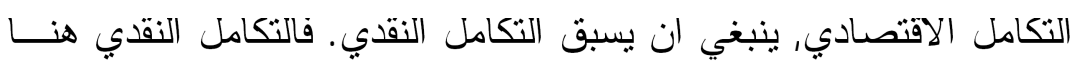
يدعم تحرير التجارة الخارجية, وتحرير حركة عو امل الإنتاج بين الدول 


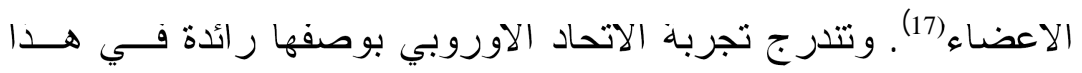

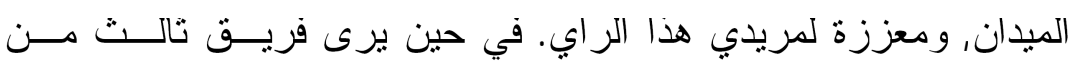

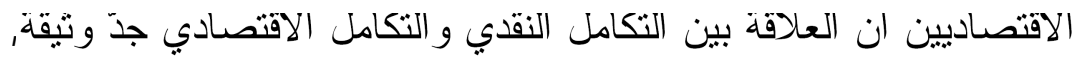

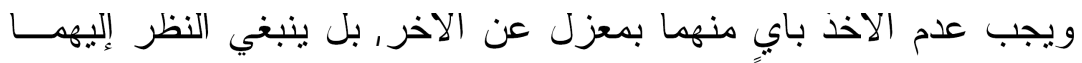

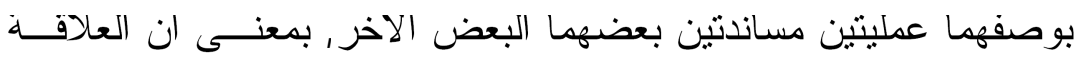

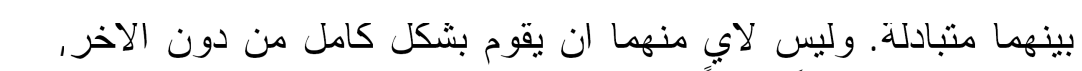

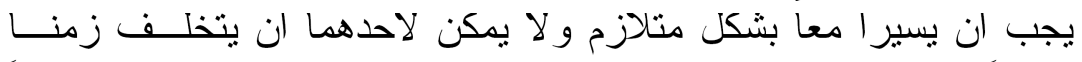

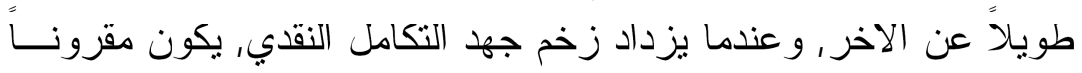

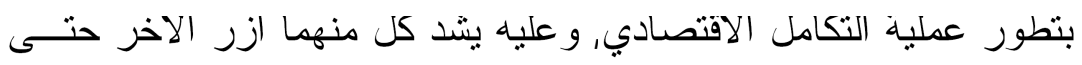

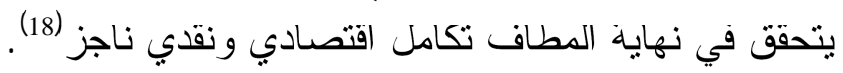

\section{تانيا: نظريه التكامل النقدي: نظريه منطقه العمله المتلى:}

يمكن عد منطقة العملة المتلـى Opى

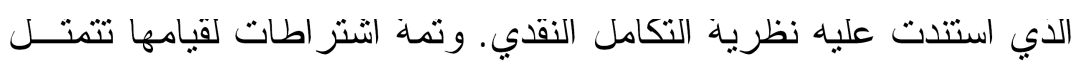
بالنقاط الاتية:19) 1. حرية حركة كاملة لعو امل الإنتاج بين دول المنطقة، وعـدم قــدرتها خار ج نطاقها.

2. قابلية تامة لعملات دول المنطقة للتحويل بعضها تجاه الاخر .

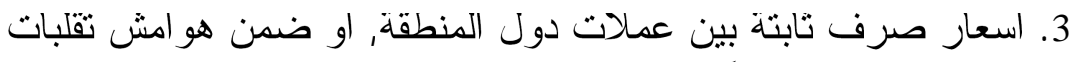
محدَّة تزول تدريجيا, بحيث تتنهي بعملة موَحدة.

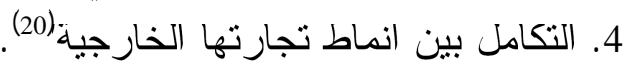
5. تحقيق مستوى عالي من التنسيق بين سياساتها المالية و النقدية.

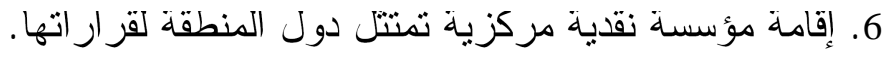

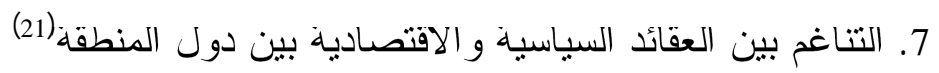


8. نو افر رغبة دول المنطقة في التنازل عن استقلاليتهم في شؤون النقـــ و الائتمان و الفائدة.

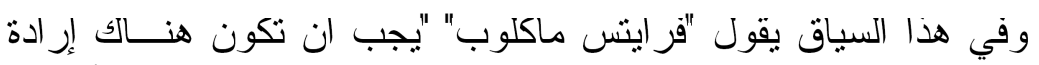

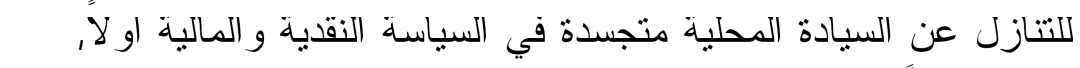
يكون ممكناً تثبيت اسعار الصرف بشكل دائر, ومن ثم ســيكون إدخـــال العملة الموّحدة تتويجاً لتحقيق الوحدة الاقتصادية و السياسية"'(22).

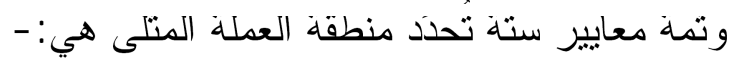

\section{Factors Mobility}

1. معيار حريه حركه عوامل الإتتاج يرى"روبرت مونديل" ان منطقة العملة المتلى هي إقليم تبدو فيه قابلية كبيرة لعو امل الإنتاج على الانتقال من الدول ذات التكلفة المتدنية او العائد

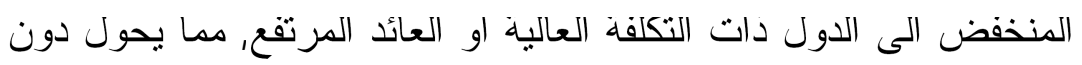

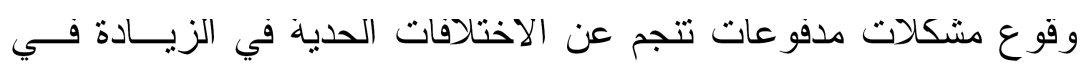

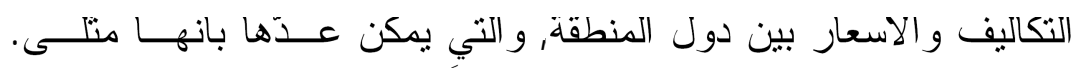

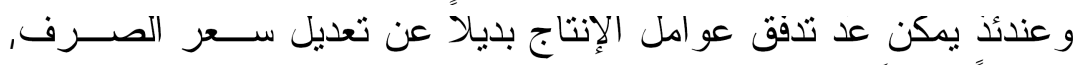

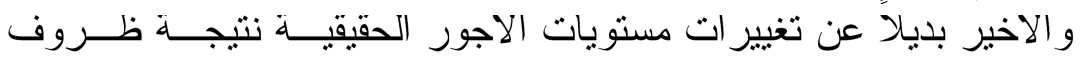
العرض و الطلب (23).

\section{2. معيار درجه انقتاح الاقتصاد المحلي ازاء التجارة الخارجيه}

Openness of Economy Toward Foreign Trade يقيس هذا المعيار نسبة السلع المتاجر بها Tradable Goods الى السلع غير المتاجر بها Non- Tradable Goods و اثز ذلك في المو اعمـــة بــين

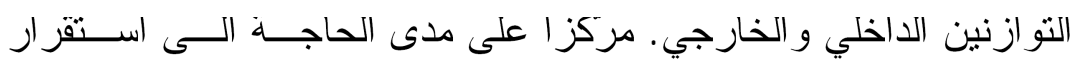

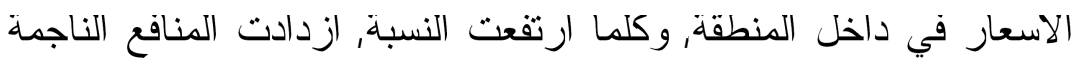

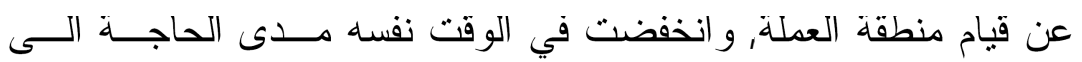


استخدام السياسات المالية و النقدية للحفــاظ علــى التــــوازن الخـــارجي.

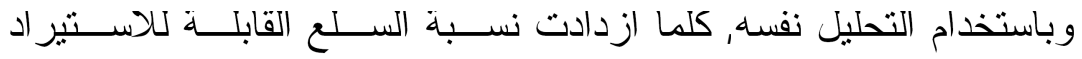

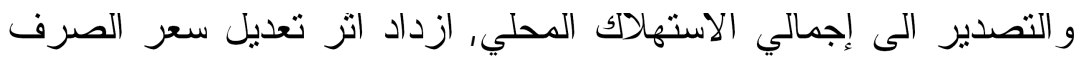

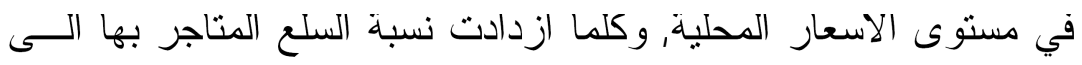

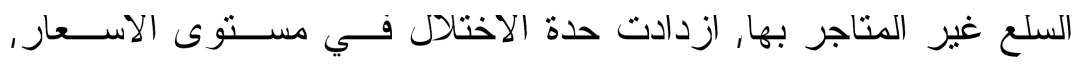

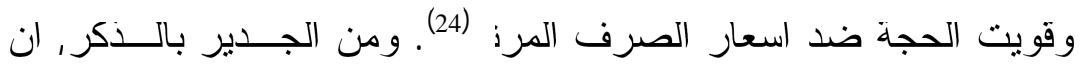

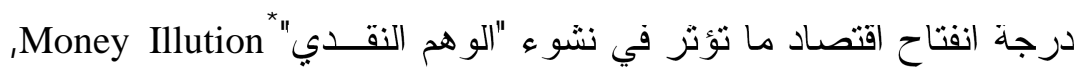

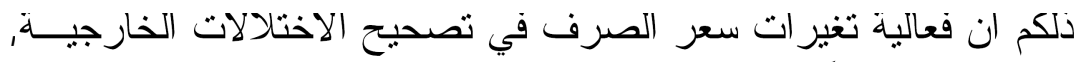

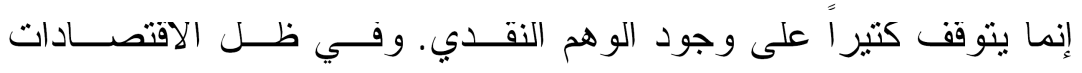

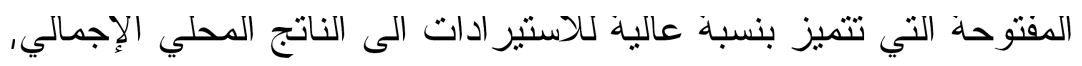

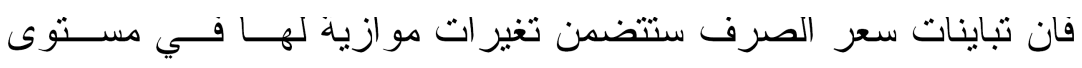

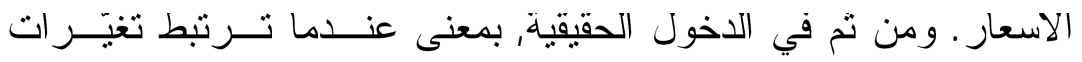

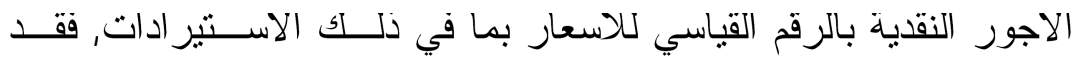

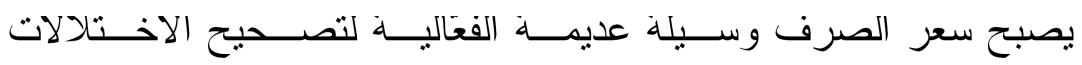
الخارجية (25).

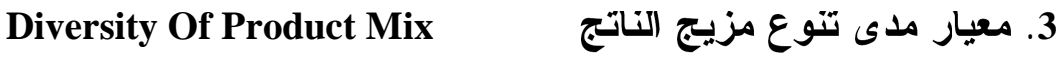

يقام "بيتز كينن" تلاث اسانيد حول هذا مدا المعيار هي: (26)

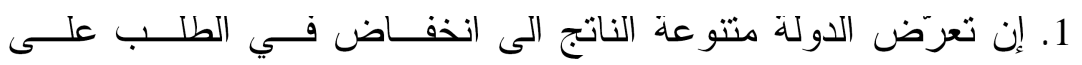

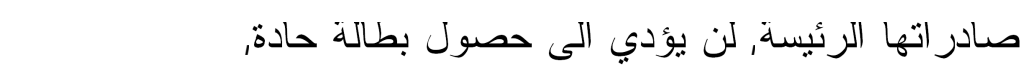
للاولة احادية الناتج.

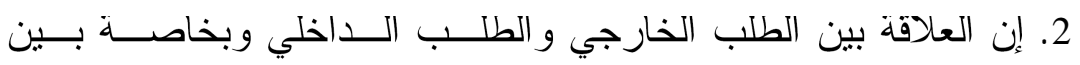

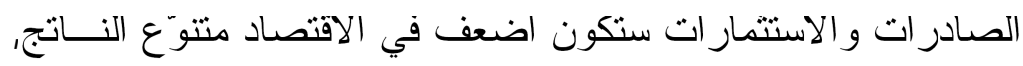

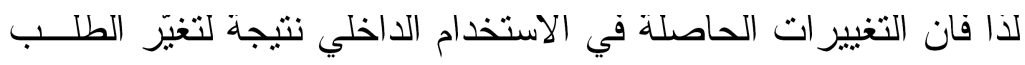
الخارجي لن تكون كبيرة. 
3. إن الاقتصاد مثتوع الناتج لن يتعرّض لتغير ات في معــدلات التبــادل

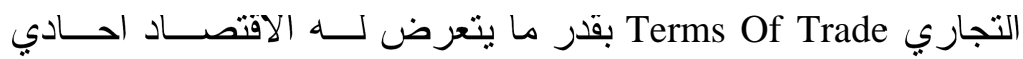

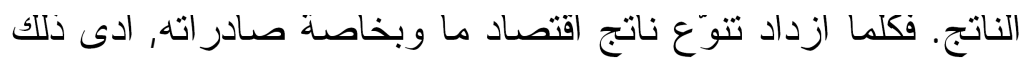
الى ابتعاده عن التقلبات الخارجية، اي بمعنى إقلاج الاتار الناجمة في

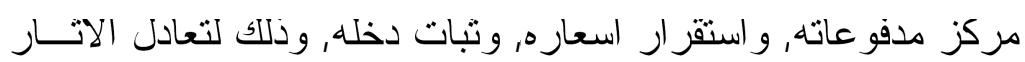

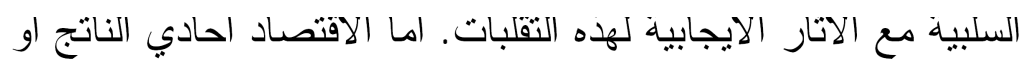

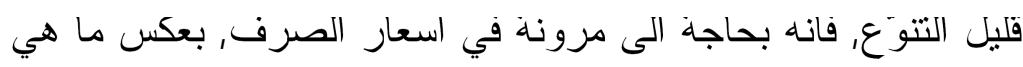
عليه حال الاقتصاد منتوَع الناتج.

إن المعايير التناث المذكورة انفا تمثل معايير ا تقليدية لتحديد النطاق

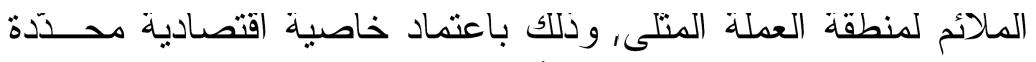

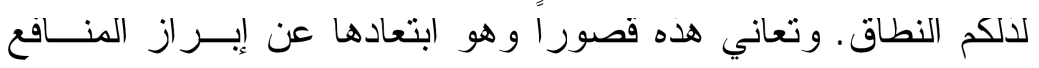

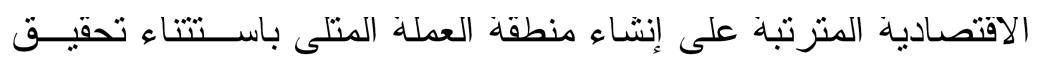

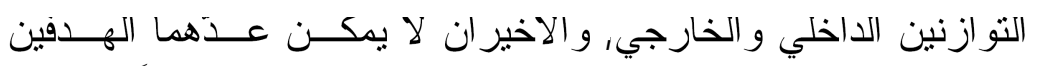

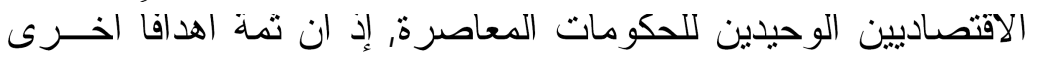

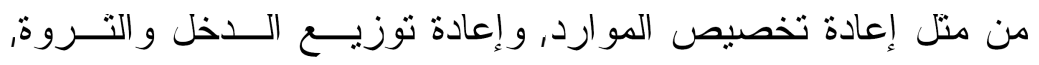
وتحقيق النمو الاقتصادي، وقد تتعارض مثل هذه الاهداف و السياسات

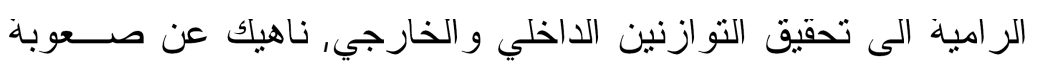

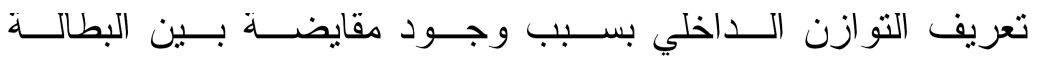
و التضخم (27).

4. معبار التكاليف و المنافع: - يعد هذا المعيار اسلوبا جديدا ومطوز ا يضع

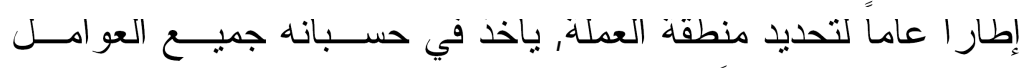

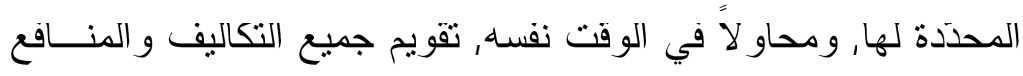

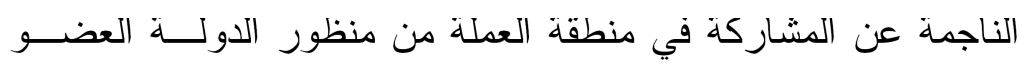

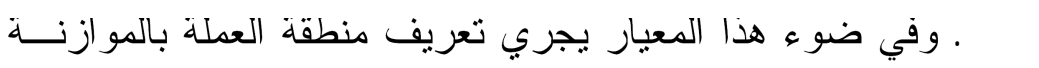


Cost- بين التكاليف و المنافع, اي على اساس تحليل الكلفة - المنفعــــا Benefit Analysis

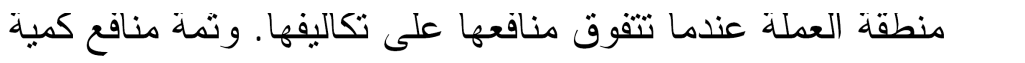

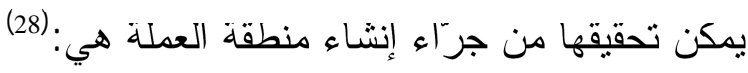
1. منافع تتجم عن الاقتصاد في الموارد الخاصة بحقل الصيرفة.

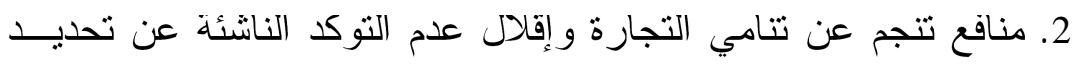

$$
\text { سعر الصرف. }
$$

3. منافع تتجم عن تحقيق كفاءة اكبر في عمل الالية النقدية. اما التكاليف الممكنة Potential Costs فتنجم عن عدم القدرة على نغيير

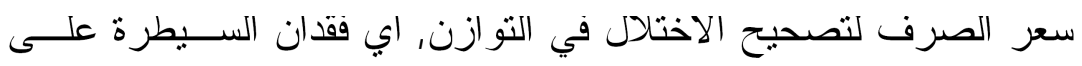

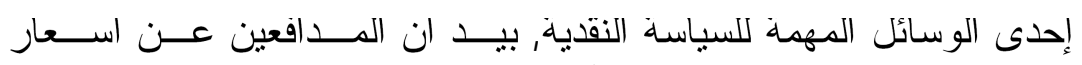

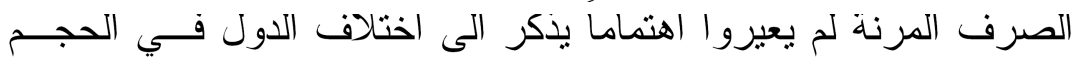

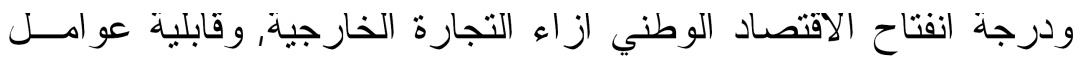

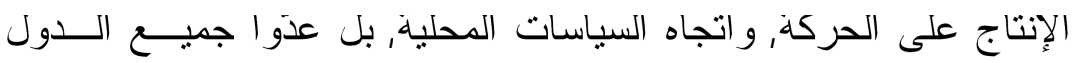
الاعضاء في منطقة العملة متساوين في كل ذلك (29).

5. معيار مدى تعرض الدول للصدمات الخارجية ودرجة استجابتها: -

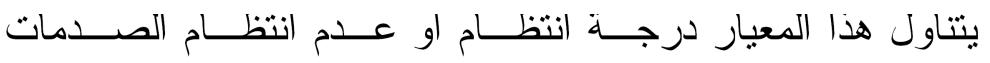

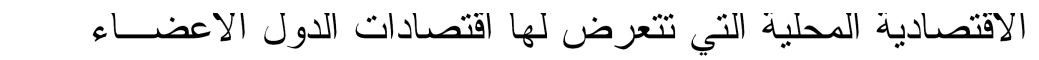

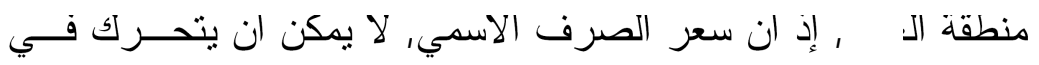

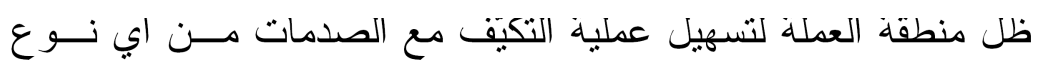

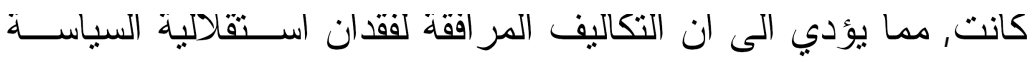
النقدية, سنزداد مع ارتقاع درجة عدم انتظام الصدمات بين دول منطقة 
لم يتسن لهذا المعيار ان يتبو ا مكانته المهمة ضمن معايير تحديد منطقة

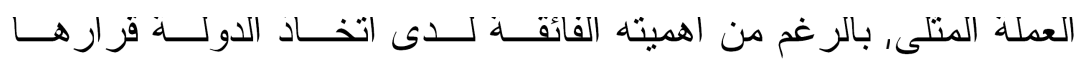
بالانضمام الى منطقة سعر صرف تابت. إد تقترض المعايير المـــكورة

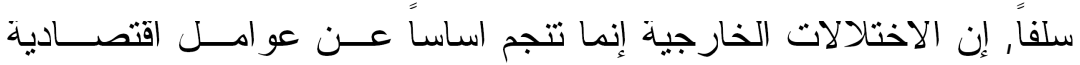
جزئية Micro Economic Factors من مثل التغير ات في ظروف العرض و الطلب في صناعات بعينها. لكن التجربة التاريخية تسفر عن ان الامــر فئر

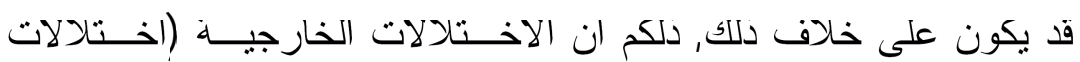

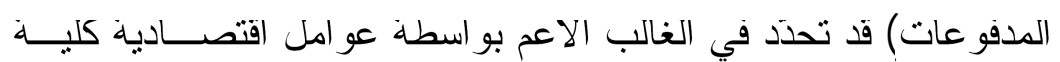
Macro Economic Factors

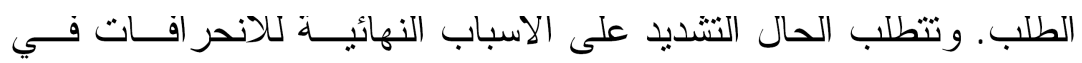

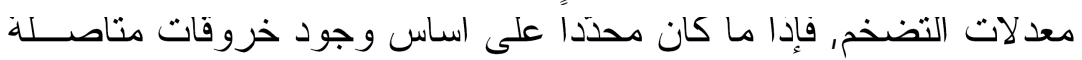
في اهداف الاستخدام على المستوى المحلي, وفي الضغوطات التي تمليها نقابات العمال, او في درجة تحكم المنتجين في الإنتاج, وفــي اتجاهــات تطور الإنتاجية.

وفي هذه الحالات, قد يتاكد الحفاظ على سعر صرف مثبت او غيـر عملي من جهة، وباهظ التكلفة من جهة اخرى. ويعتقد بعض الإقتصاديين إن الانضمام الى منطقة العملة، قد يكون في حد ذاته وسيلة فعَالة لتصحيح

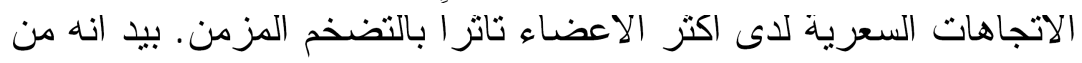

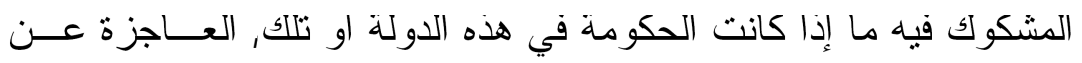

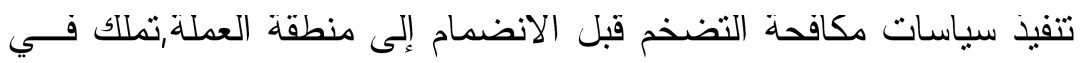

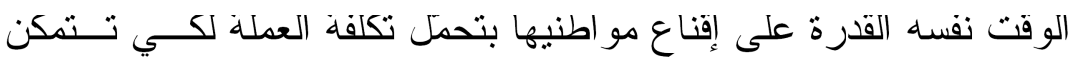
ببساطة من الحفاظ على سعر الصرف المثبت المتّق عليه(30). وفي ضوء استعر اض معايير منطقة العملة المثلى, يمكن التوصل إلى الحقائق الاتبة (31): 


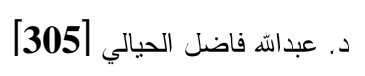

م إن منافع منطقة العملة بين عدد من الدول يمكن ان تــزداد, إدا كــــان

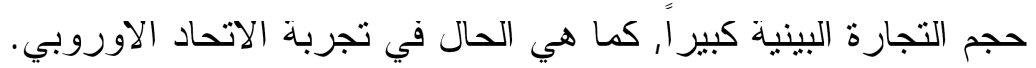

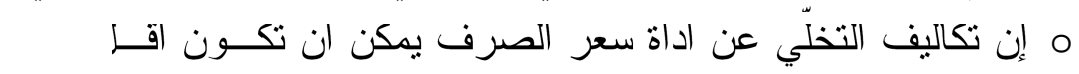

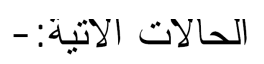

- إذا كانت قابلية العمل وراس المال على الدركة بين الدول الاعضـــاء

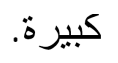

- إدا كان اقتصاد كل دولة عضو دا بنية صناعية متتؤعاةريــنجم عنهـ صادر ات متتو"عة الناتج.

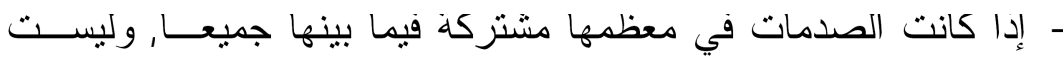

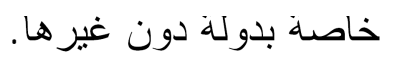

المبحت التاني: إنشاء منطفه العمله المتلى ومحداتها لاول مجلس التعاون لدول الخليج العربيه:

اولا: مدى إمكانيه إنتاء منطفه عمله متلى بين دول المجلس:

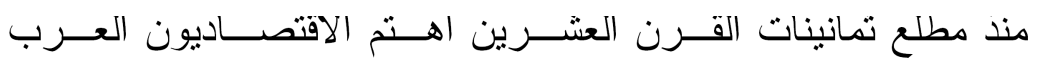

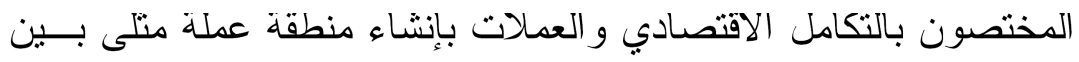

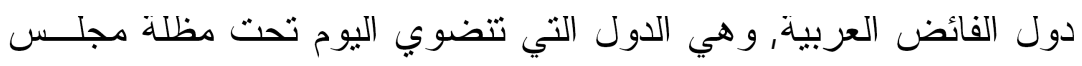

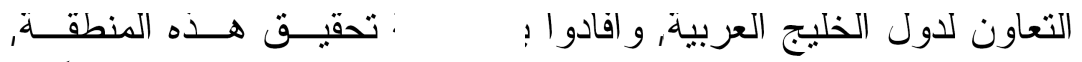

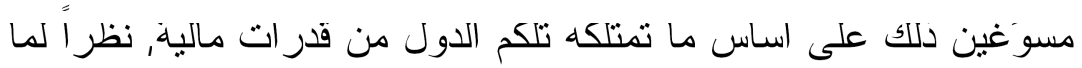

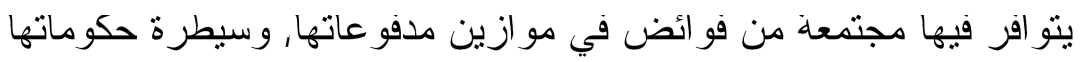

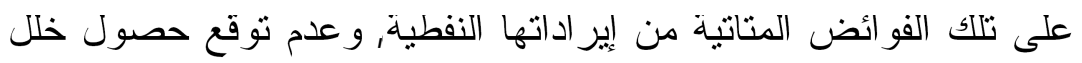

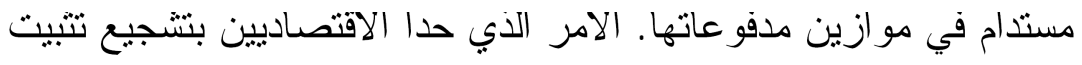

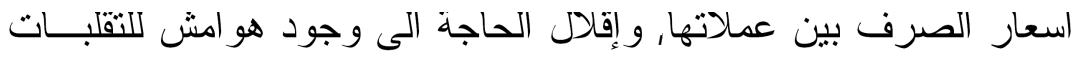

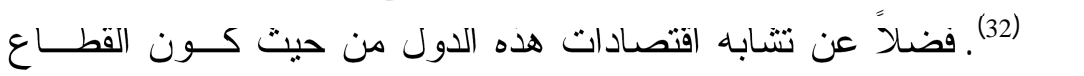


النفطي يشكل معظم دخولها القومية, وهذا يعني ان بالإمكان إنشاء منطقة

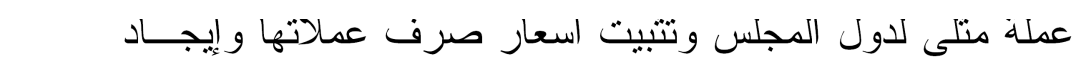
موَحدة بينها, في حين ان هناك اشتر اطات اخرى وبخاصة السياسية منها,

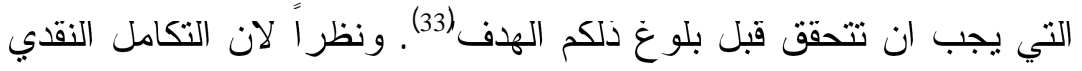

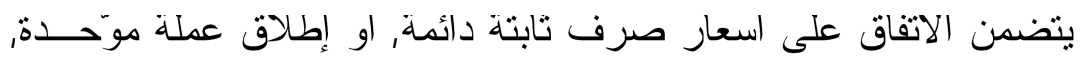

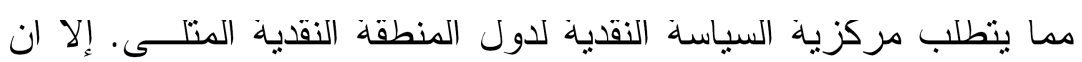

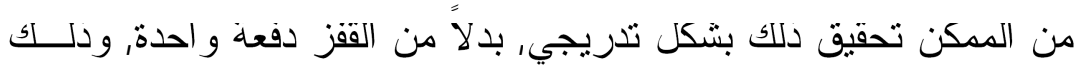

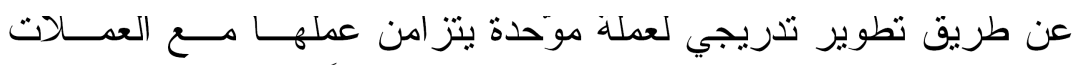
المحلية القائمة. ونتز ايد نسبتها الى الاخيرة تدريجياً وباستمر ار مع مرور الزمن (34). ويجري تداولها مع العملات المحلية، الى ان يصبح دلك امــراً

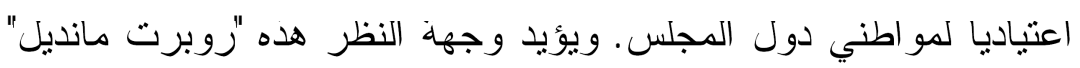
المتخصص في العملات إذ يؤمن بضرورة تبني العملة الخليجية الموّحدة

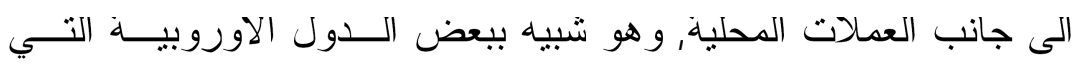
تتعامل بعملتين هما العملة الاوروبية الموحدة (اليورو), و عملتها المحلية, وسياتي اليوم الذي ستتخلى فيه دول المجلس عن التعامل بعملاتها المحلية,

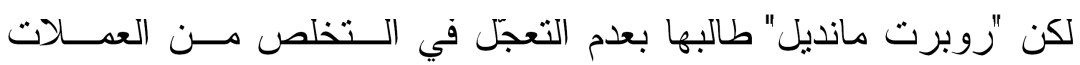
المحلية حالياً(35).

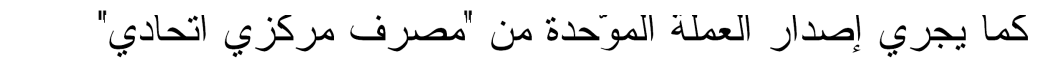

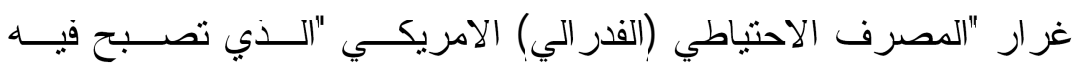
المصارف المركزية لدول المجلس اعضداء عاملين تسهم فيه بنسبة مـنـ

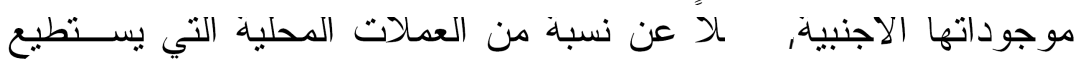

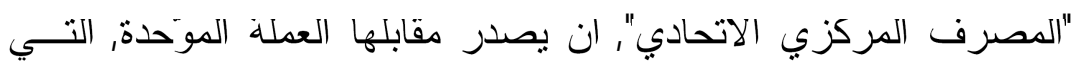

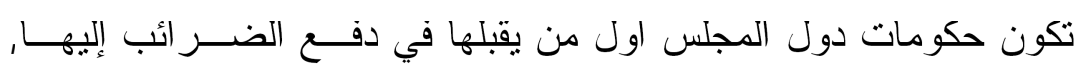
وتسديد الالتزامات تجاهها, وتكون المصارف التجارية اول من يستخدمها 


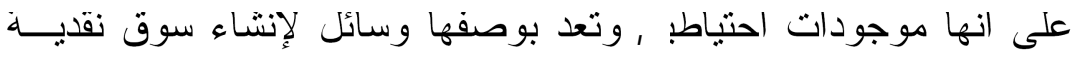

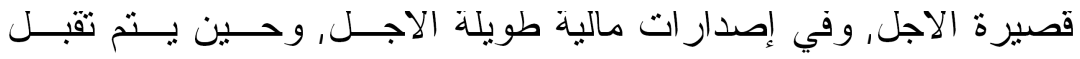

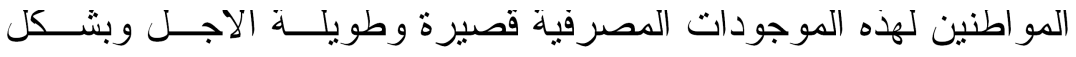
تدريجي, يمكن عندئذ للمصرف المركزي الاتحادي استخدام هذه السندات

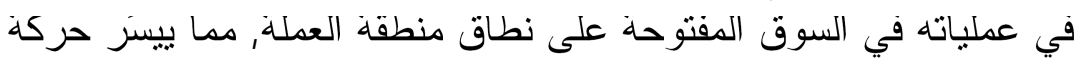

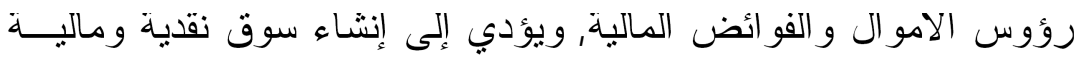

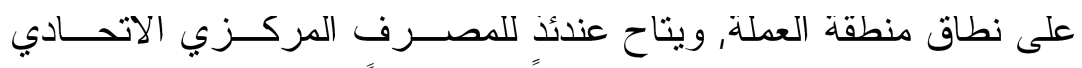

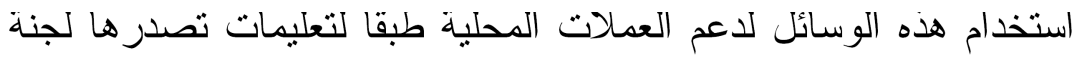

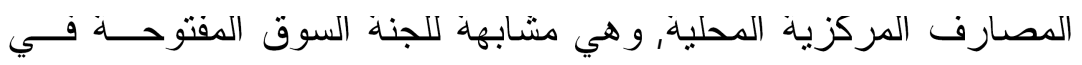

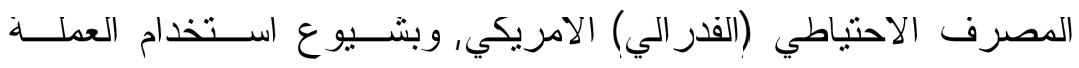
الموحدة سيكون بإمكان هذه العملة ان تحل محل العملات المحلية المتعددة

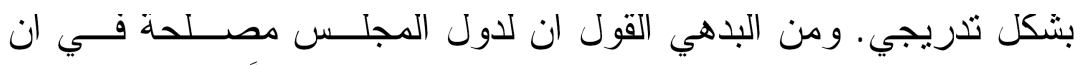

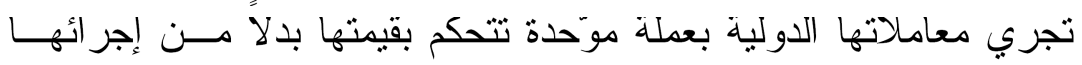

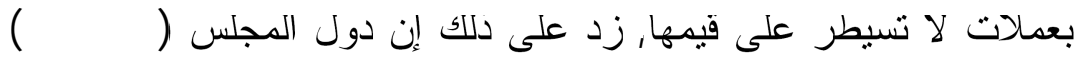

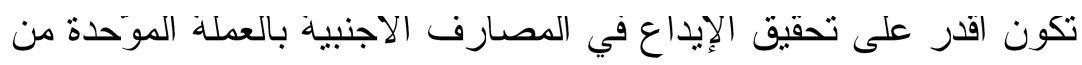

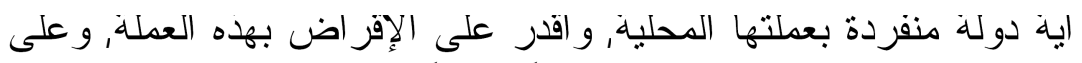

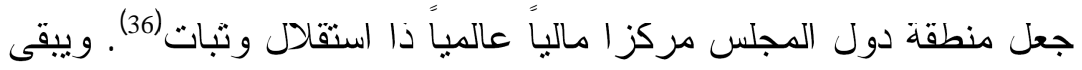

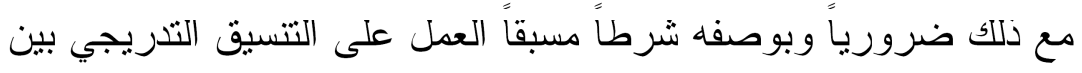

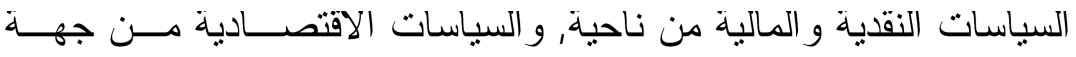

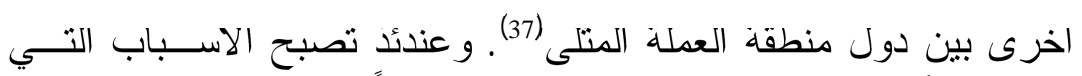

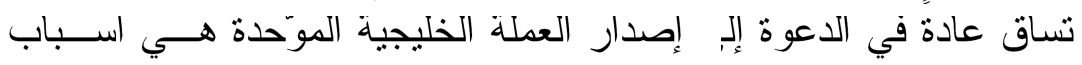

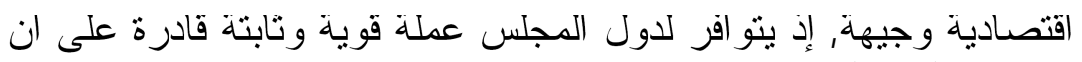

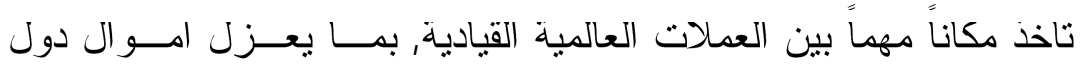


المجلس في التعاملات المالية عن انخفاضات قيم العملات الاجنبية التـي تستخدم نظر اً لتاكل قيم ارصدتها المالية في الخارج.

\section{تانيا: محددات منطقه العمله المتلى لاول المجلس:}

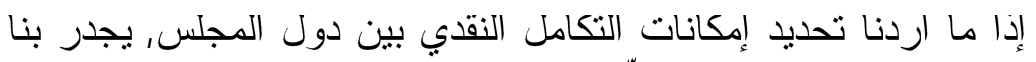
ابتداء إنبات ان هذه الدول نشكِّ منطقة عملة منلى وبحسب ما يتو افر لها من إمكانات اقتصـادية تحقق ذلك, ويتجسد الامر من الناحية العملية فـي مئي

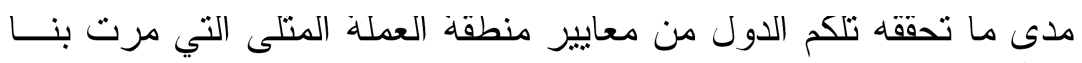

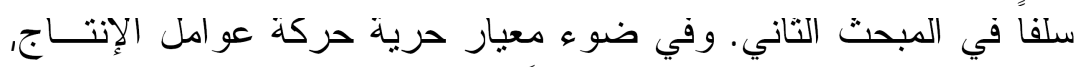

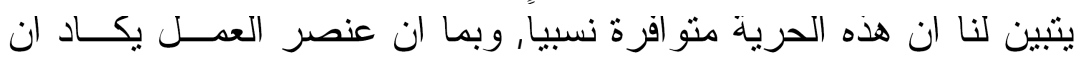

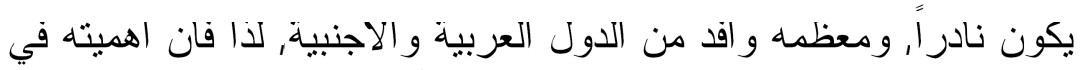

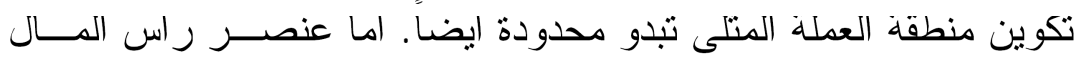
النقدي, فحرية انتقاله مضمونه، وليس تمة قيود على حركته سو اء اكـــان

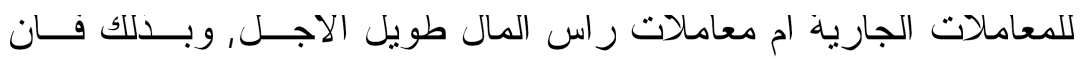

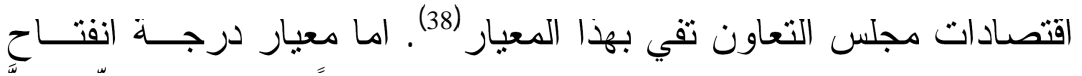

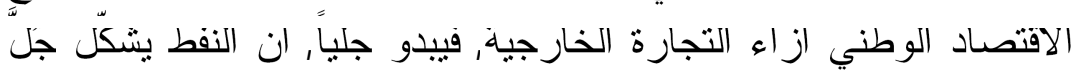

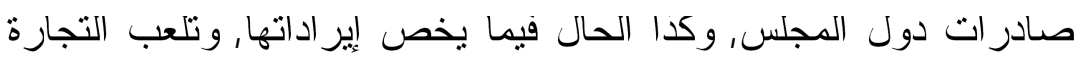

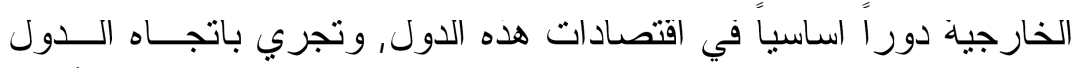

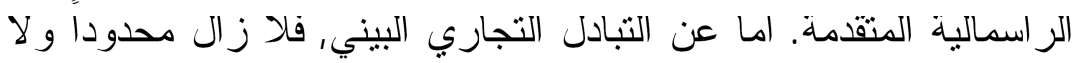

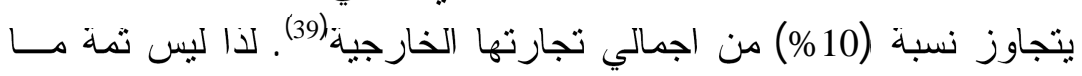

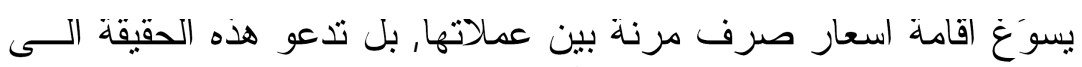

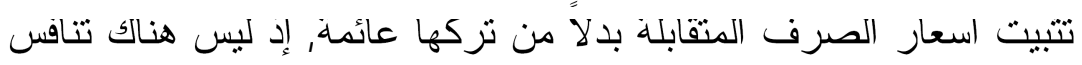

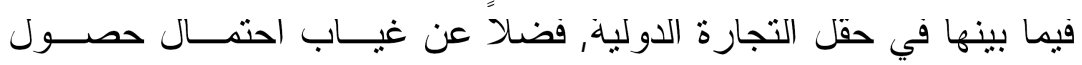

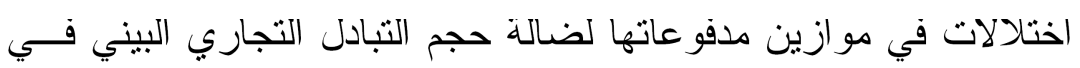

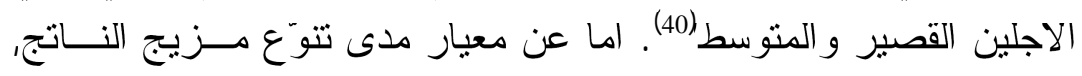


فنجد ان الناتج الرئيس لهده الدول منتسابه، وهو النفط, مما يجعلها منطقة

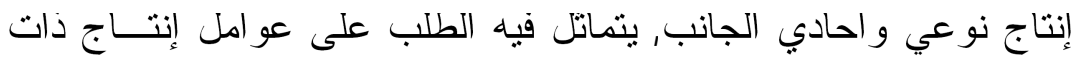

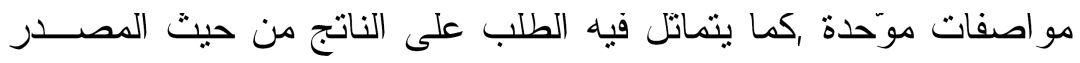

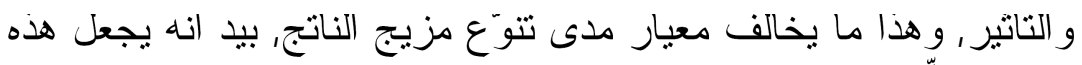

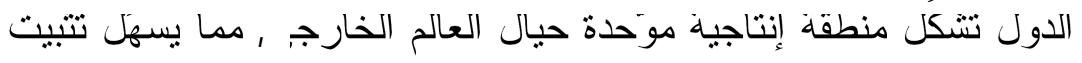

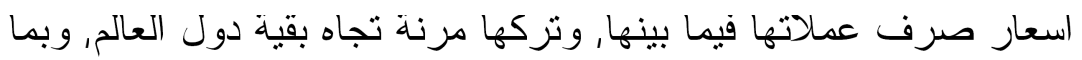

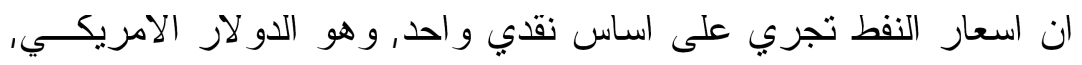

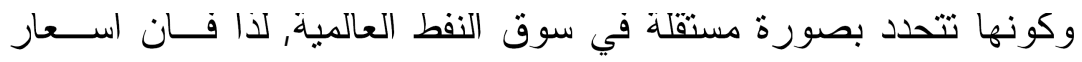

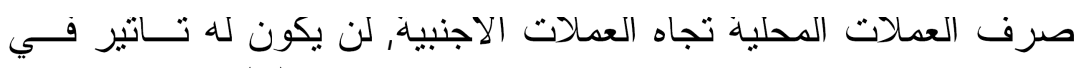

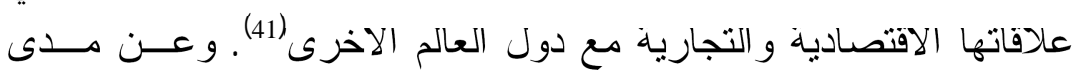

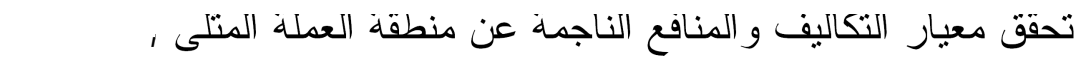

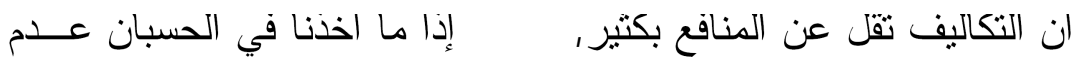

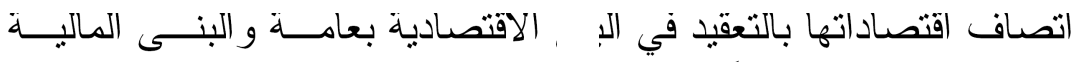

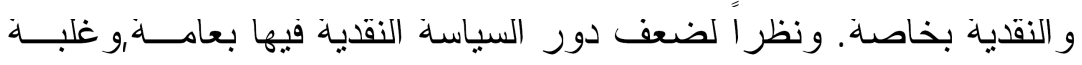

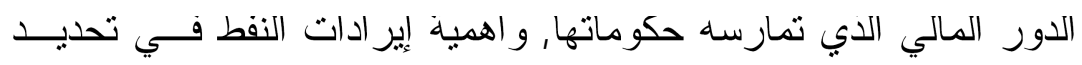

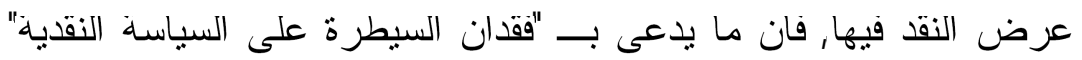

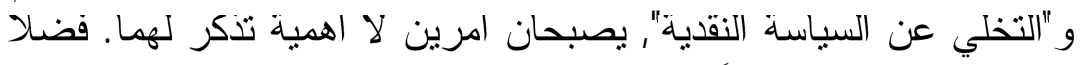

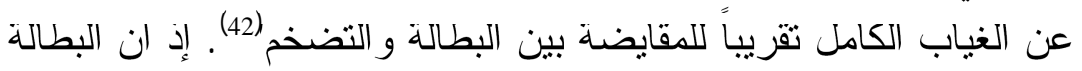

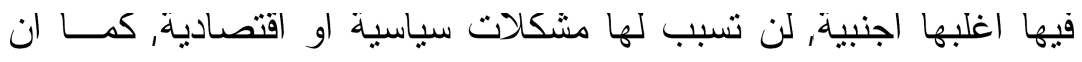

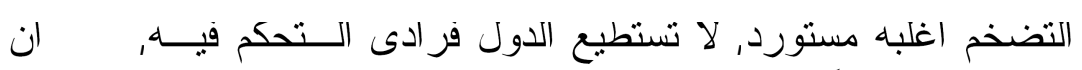

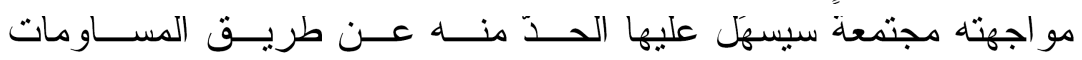

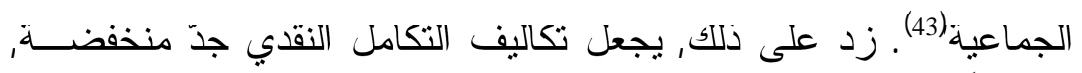
مقارنة "بالمنافع التي يمكن ان تحصل عليه دليها دول المجلس (44). 
اما عن معيار مدى تعرّض الــدول للصــدمات الخارجيــة ودرجـــة استجابتها, فكما مر بنا سلفاً, ان دول المجلس منفتحة اقتصادياً, لذا تكون ودئ

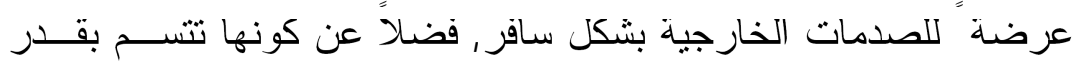

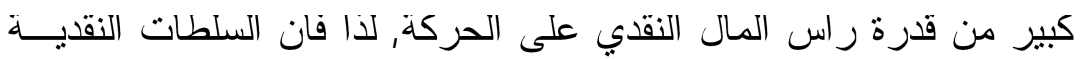
فيها, لن تتمتع بقدر كبير من الاستقلالية في صنع السياسات النقدية، ومن

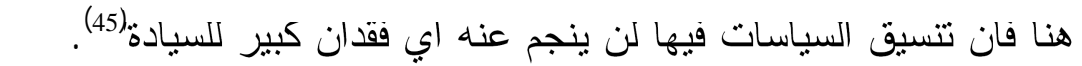

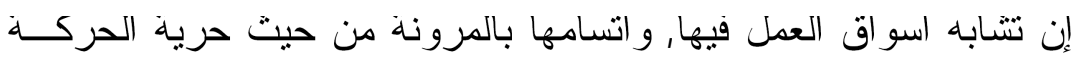

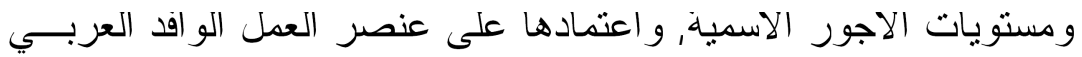

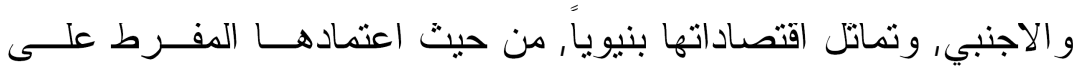

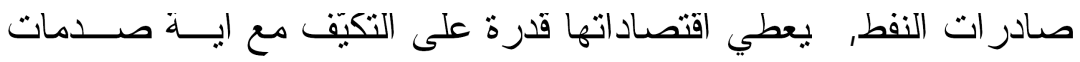

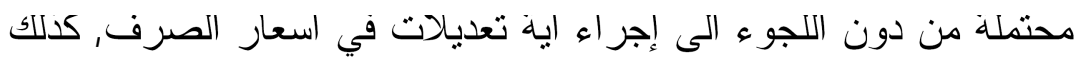

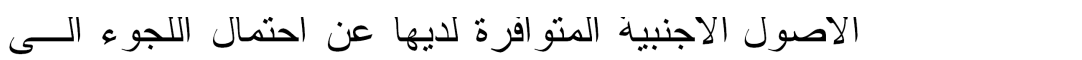
معالجة الازمات المالية إن وقعت بطبع النقود, كما سيجعل من اية صدمة الاجنة

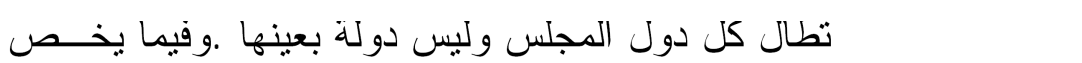

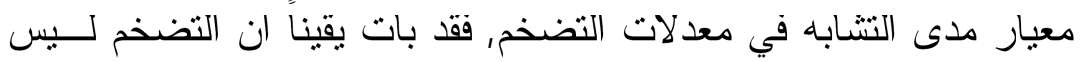
ناجماً عن عو امل داخلية من مثل ضغط في الطلب, او قصور في الإنتاج, فئاس

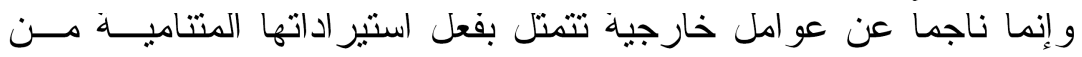

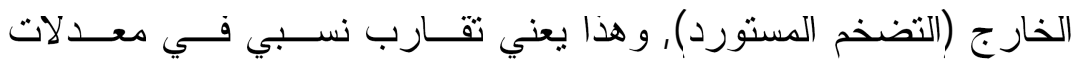
التضخم, الامر الذي يسهل عليها التنسيق بين سياساتها المالية و النقدية في

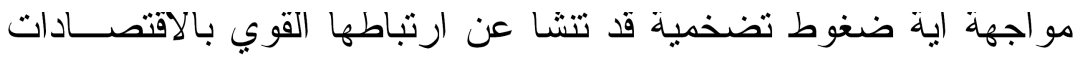
الر اسمالية المتقدمة(46). وفي ضو ضوء تلكم المعايير نخرج بنتيجة فحو اها ان

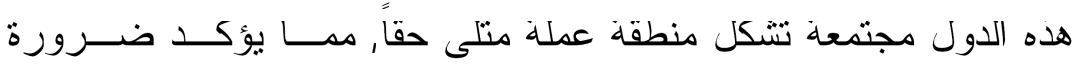
إمكانية اتباعها سباسة اسعار صرف تابتة بين عملاتها, بوصفها خطـــوة تمهيدية نحو تحقيق التكامل النقدي فيما بينها. 
ومما يدعم هذا التوجها، تماتل السياسات الاقتصادية و المالية و النقديـــة و التجارية بين دول المجلس, فالتشابه الو اسع في السياسات المالية يتشتـلـل

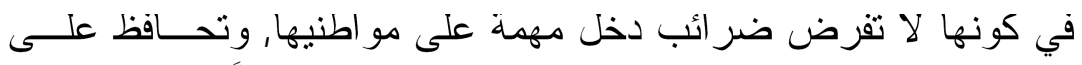

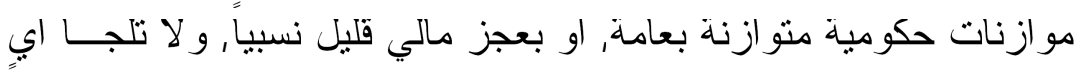

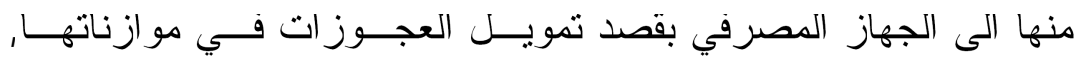

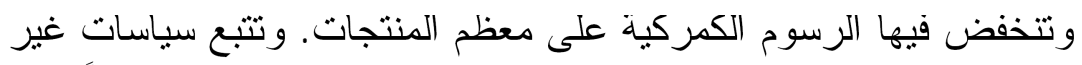

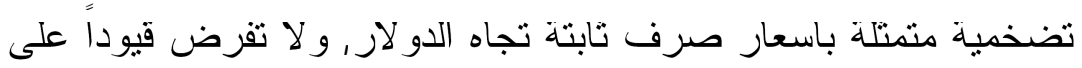

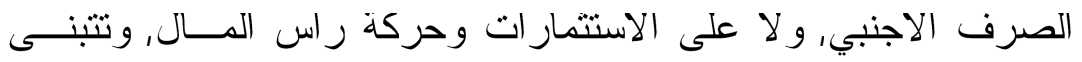

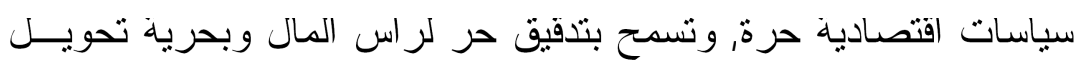

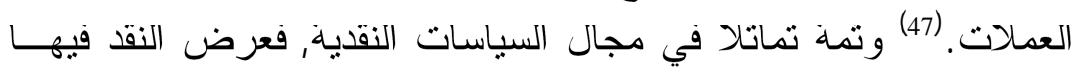

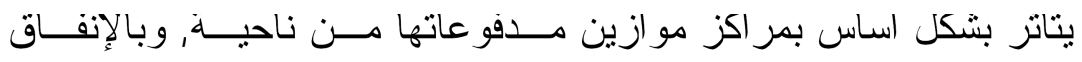

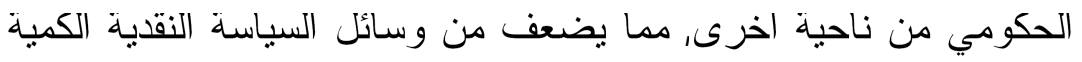

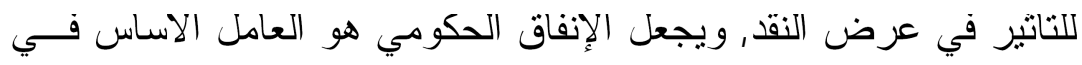

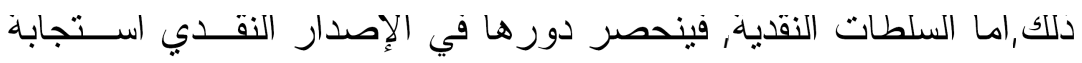

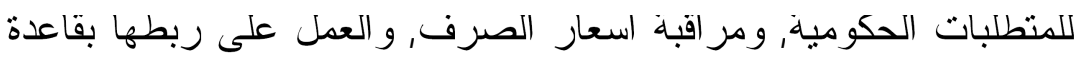

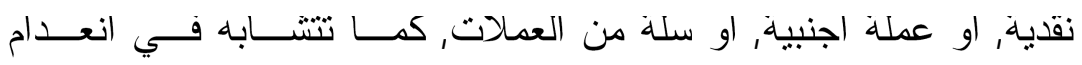

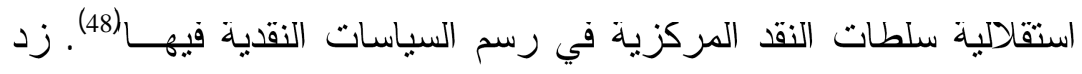

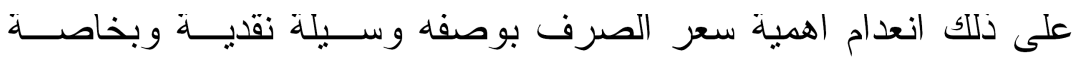

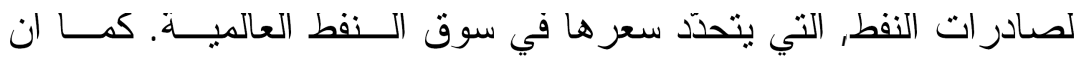
توحبد سعر الصرف, سيجعل هذه الدول منطقـــة موّحسـدة تجــاه العــالم

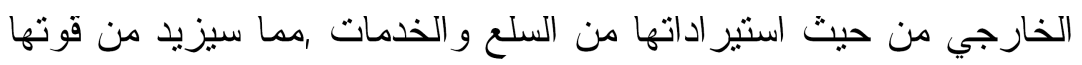

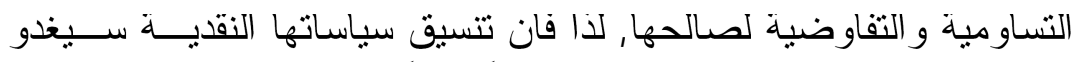

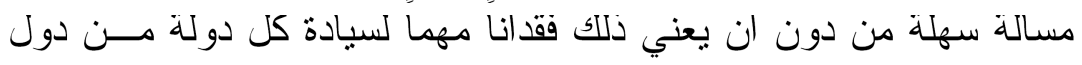

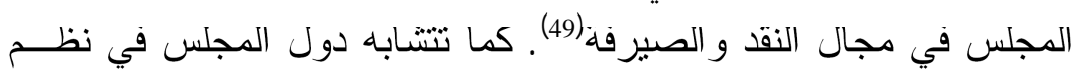


التجارة, وفي المؤسسات الاقتصادية القائمة, و ان هذا التشابه يفتح الابو اب

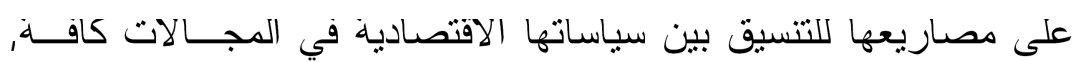
ويضمن عدم تعارضها وبخاصة في مجال اسعار الصرف.

المبحث التالت: اسلوب التكامل التفلـي وصيغته وتوحيـــ نظــام ســعر صرف العمله المتلى لاول مجلس التعاون لدول الخليج العربيه اولا: اسلوب التكامل النقدي لدول المجلس وصيغته إتخذت قمة مسقط (2001) قر ارين مهمين بشان إقامة تكامل نقدي بين دول المجلس هما: 1) اعتماد الاسلوب التدريجي في إقامة التكامل النقدي علــى ان بجــري العمل فيه في الاول من كانون التاني عام 2010.

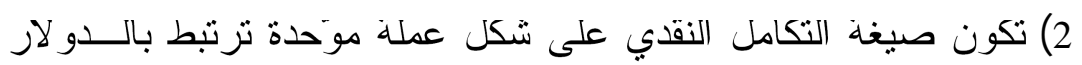

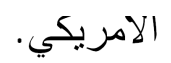
وقد انعكس قرار الاسلوب التنريجي في تبني معايير اداء اقتصادية في

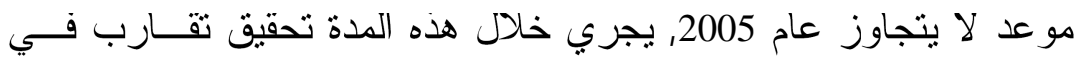

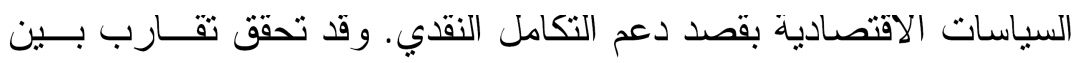
سياسات سعر الصرف التي اعتمدتها دول المجلس بشـان الربط بالـــدو لار الامريكي بسعر صرف ثنابت في عام 2002. ومنذ كــانون التــاني 2003 اتخذت دول المجلس خطوات عملية باتجاه دعم التكامل الإتصادي، ودعم ونم

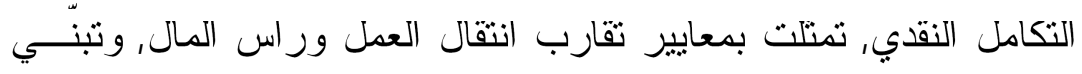

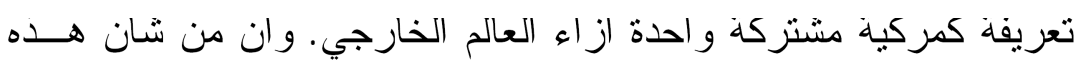
التقاربات تحقيق التكامل النقدي, و إطلاق العملة المؤحدة في كانون التاني

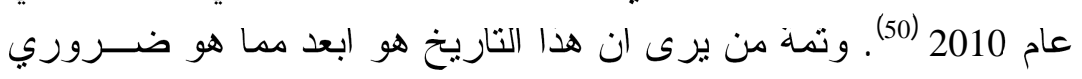

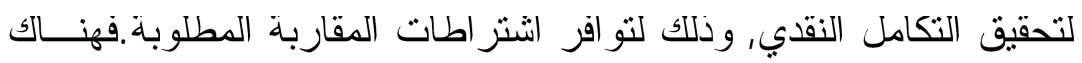




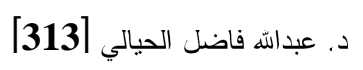

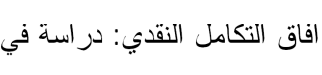

اتساق في اهداف السياسات النقاية ووسائلها, وتتسيق كامل في سياســات

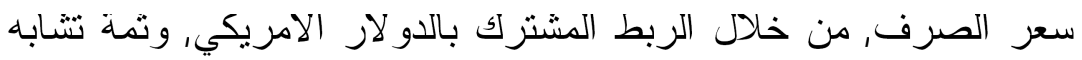

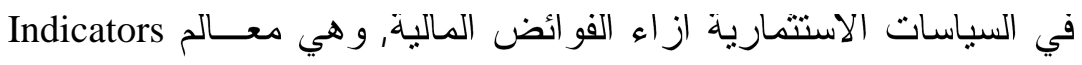

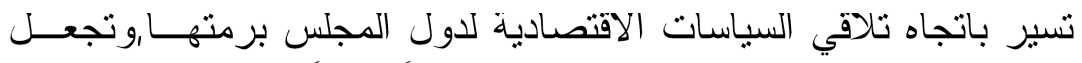

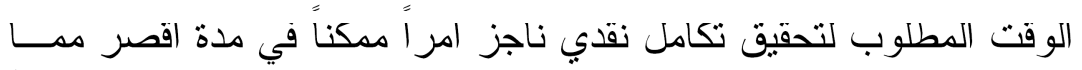
جرى التخطيط له في قمة مسقط (2001). ومع دلك قد لد يكون التاني مفيداً

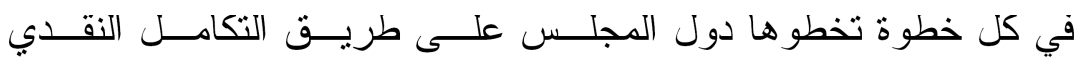
المنشود (51).

اما الصيغة التي ينبغي ان يتم بها التكامل النقدي بين دول المجلس,فقد

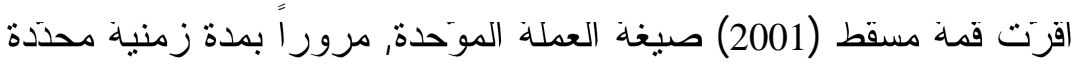

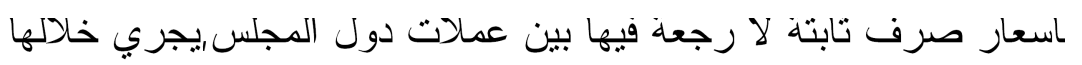

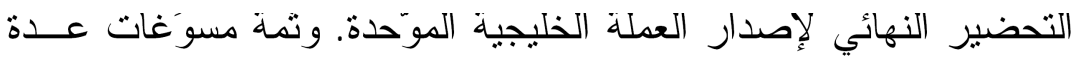
تقف ور اء اختيار تلكم الصيغة لعل في مقدمتها: ان إصدار عملة موَحدة, لقارة يعد وسيلة منلى لتحقيق تتسيق بين السياسات الاقتصادية و النقدية و المالية

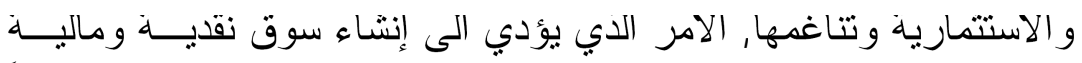
موّحدة, وفرض سعر صرف موّحد تجاه اي من العماتلات الاجنبية تمهيداً

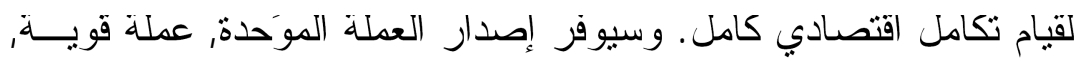

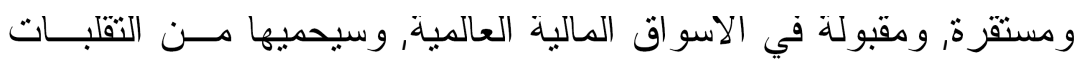

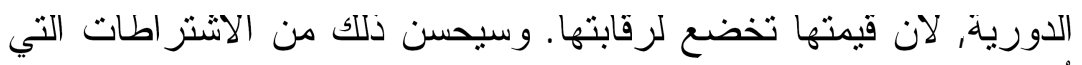

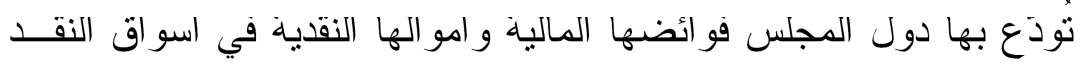

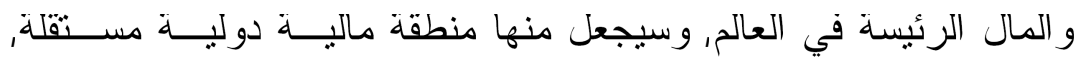

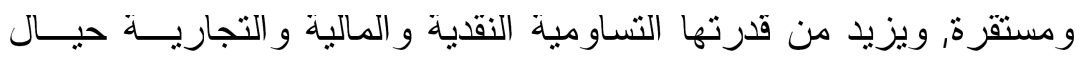

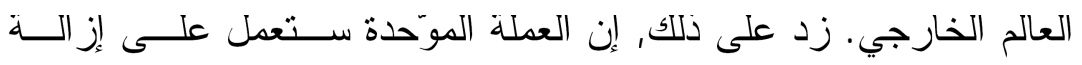

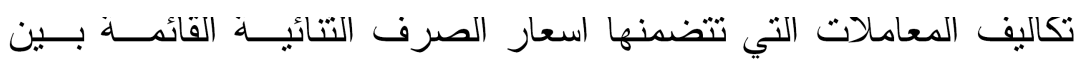




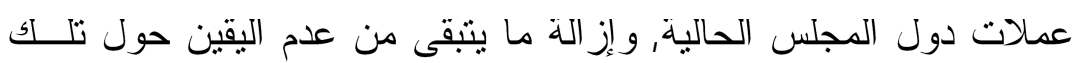

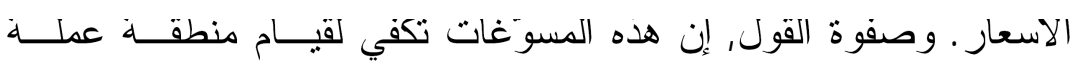
خليجية مثله, تشكل تكامل نقدي خليجي عربي مر غوباً فيه(52).

\section{تانيا: توحيد نظام سعر صرف العمله الموحدة لدول المجلس:}

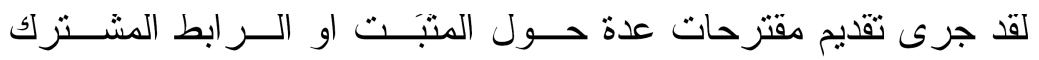

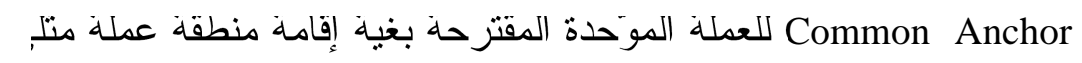

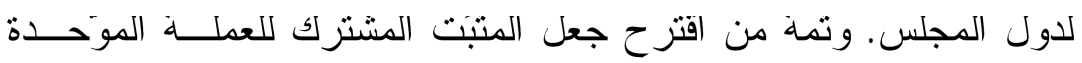

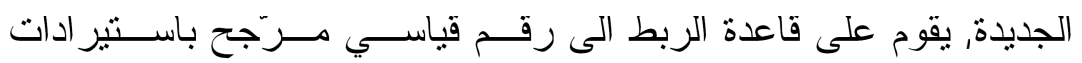
Import-Weighted Index اقتصـاديا, هو ان مثل هذا الربط لا يعكس اهمية كون معظــم صــادر اتها

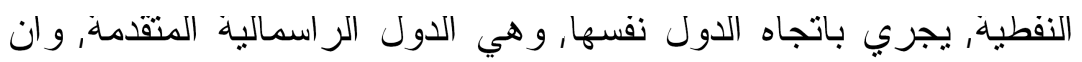
هذا الخيار سيترك لدول المجلس حريـــة اختيــار العـــلات و واوز انهـــا,

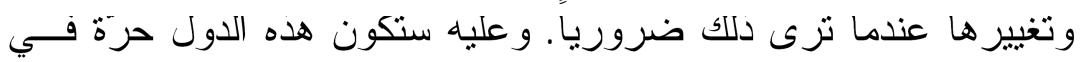

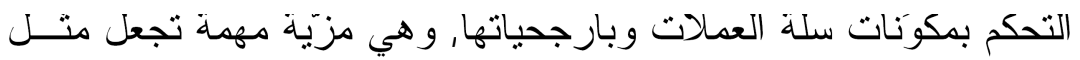

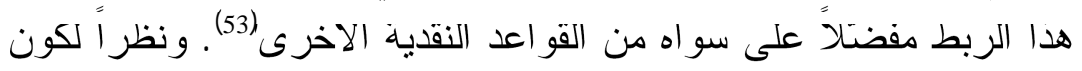

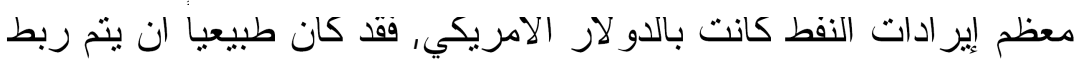

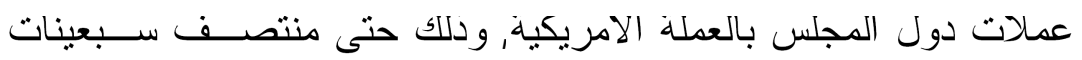

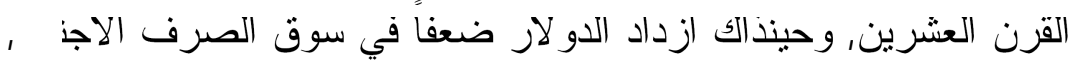

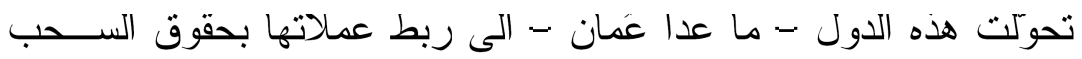
الخاصة او بسلة خاصة من العملات, تتو افر فيها هو امش كبيرة للتقلقبـات

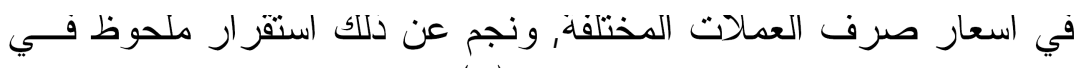

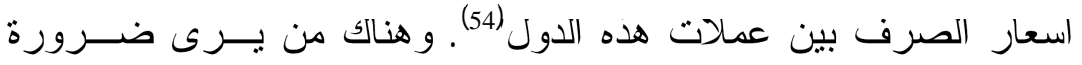

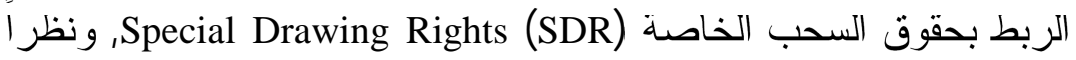

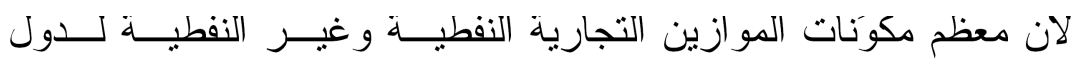




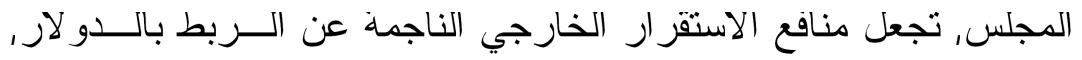

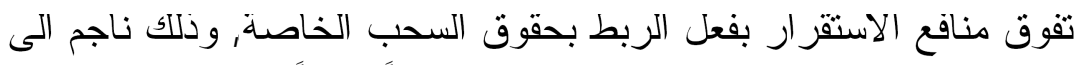

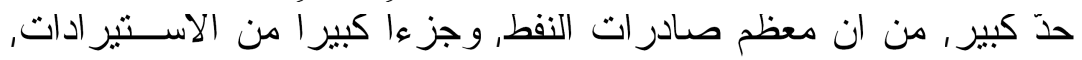

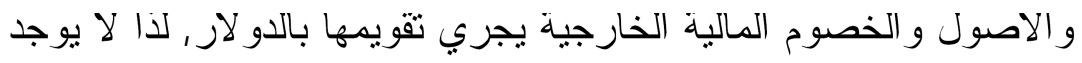

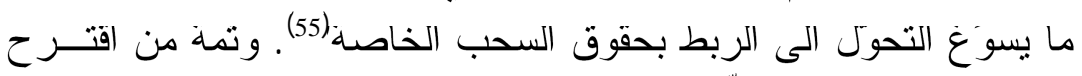

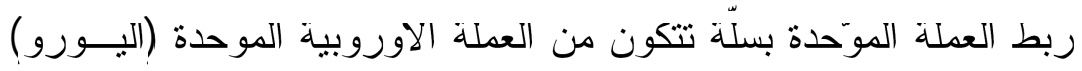

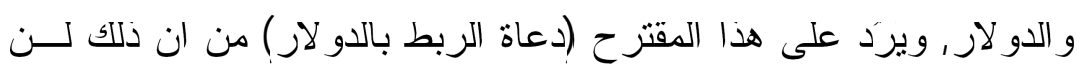

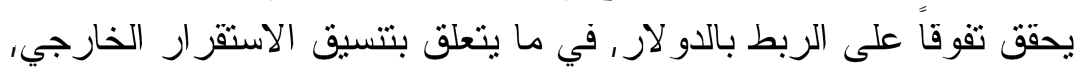

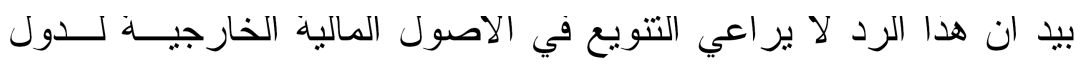

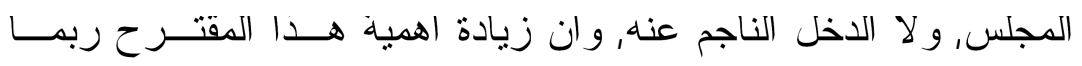

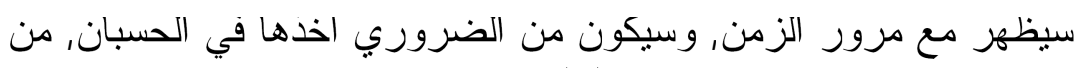

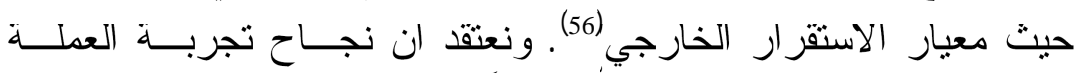

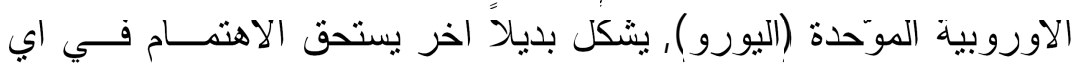

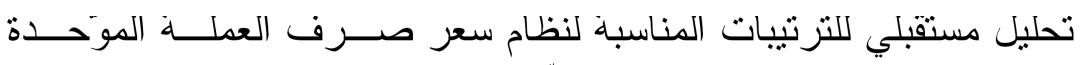

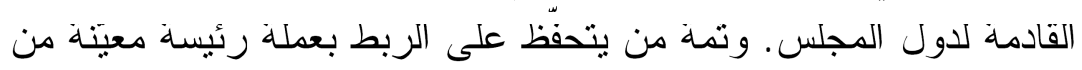

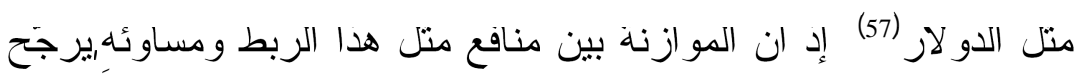

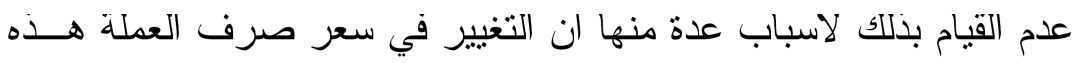

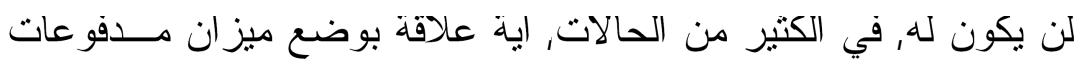

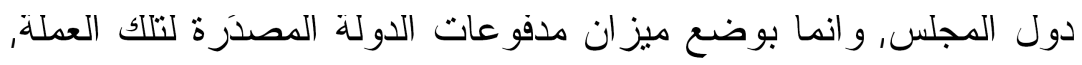

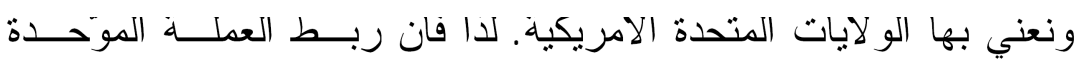

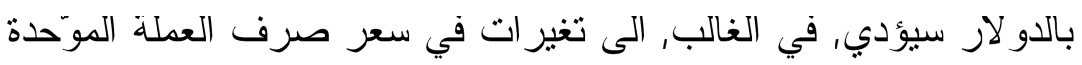

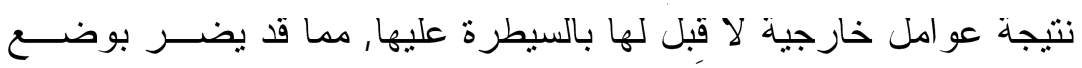

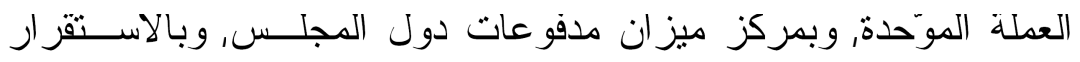
الداخلي لمستوى الاسعار فيها, ويترتب على ذلك الحاجة إلى احتياطيـات 
اجنبية اكثر مما سيكون عليه الحال في ظل نظام اسعار الصرف القابلـــة

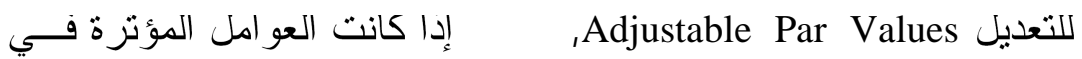

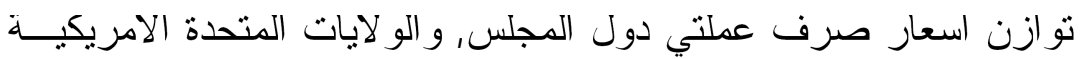

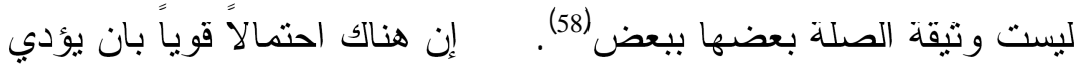

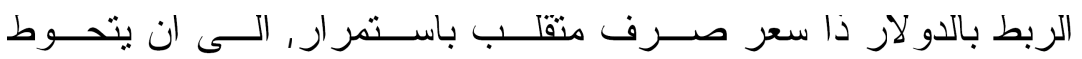
المصدرَون في الو لايات المتحدة الامريكية ضد هذه التقلبات, برفع اسعار سلعهم المصدرّة الى دول المجلس لمواجهة عدم التوكد من مسيرة اسعار

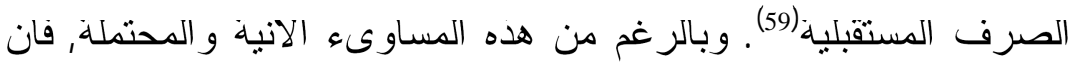
متابعة متانية للتزتيبات الخاصة لاسعار صرف العملات الخليجية العربية

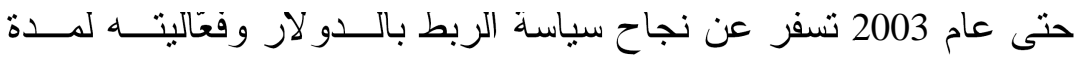
طويلة من الزمن, مما ضمن لها الحفاظ على معدلات تضخم منخفضـــة,

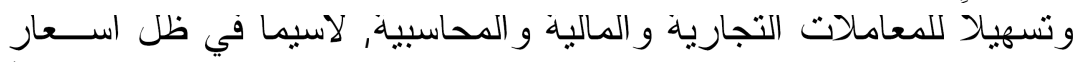
النفط ومشتقاته المقيمة بالدو لار (60). وتم في مطلع عـــام 2003, وتتفيــذاً

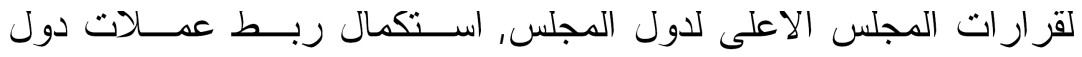
المجلس بالدو لار الامريكي بسعر صرف ثابت, وجاءت هــذه الخطـــوة

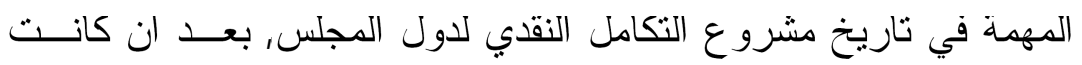
اسعار الصرف التقاطعية بين خمس عملات من اصل ستة ثابتــة لمــــة تقارب العقدين من الزمن, بالرغم من الربط الرسمي المدكور انفاً. وكان

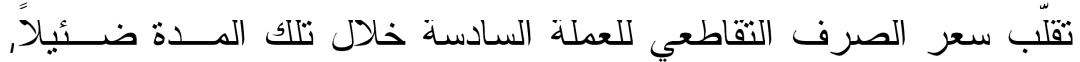

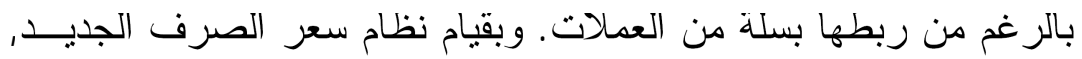
اضحى الدو لاز المتبت المشترك لعملات دول المجلس، مما الغى مخاطر

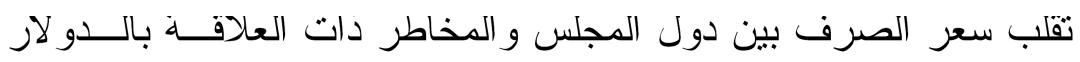

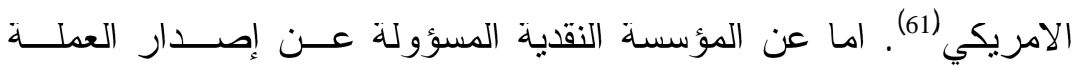

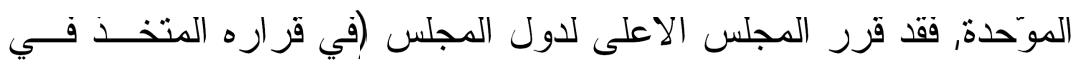


19-18 كانون الاول عام 2005) إنشـاء "السلطة النقدية المشــتركه" التـي

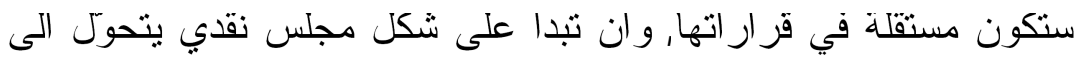

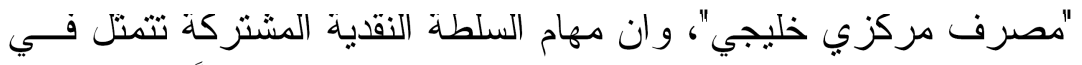

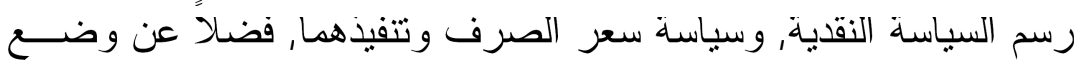

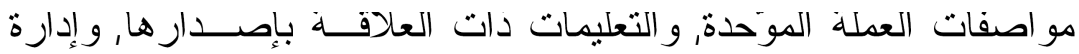
احتباطياتها الاجنبية(62). وفيما يخص تسمية العملة الموَحدة ومو اصــفاتها وفئاتها, وطبعها, وتحديد موعد إطلافها في الاسواق، لم يجر الاتفاق عليه

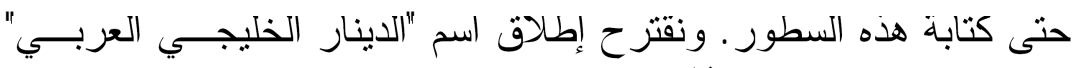

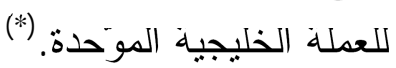

المبحث الرابع: اهاق التكامل النقدي لدول مجلس التعاون لدول الخليج

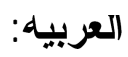

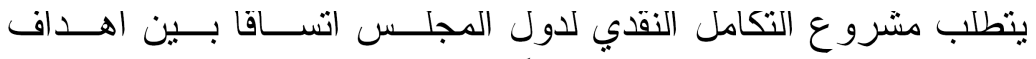
السياسات الاقتصادية المحلية, وتتاغما بين المتغير ات الاقتصادية المتمتلكة

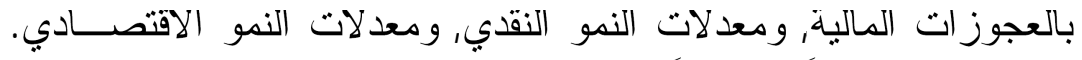

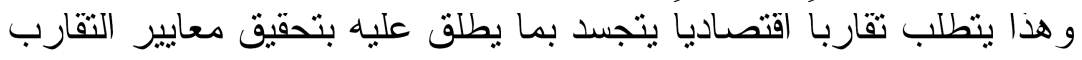
Convergence Criteria

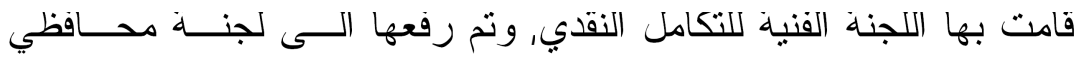

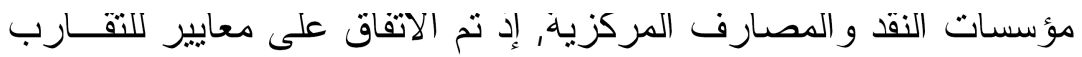

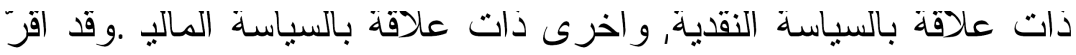
المجلس الاعلى لدول مجلس التعاون في دورة انعقاده السادسة و العشرين العادين في 18-19 كانون الاول من عام 2005 ما اتققت عليه لجنذ التعاون المالي

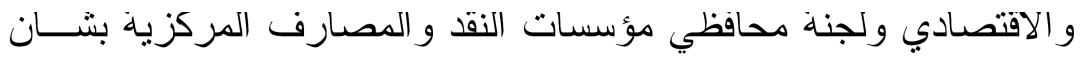

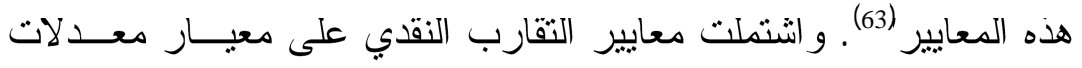


الفائدة, ومعيار معدلات التضخم, ومعيار مدى كفاية احتباطيات السـلطة النقدية من النقد الاجنبي. و هذه المعايير ذات صلـة وثيقة بالسياسة النقدية,

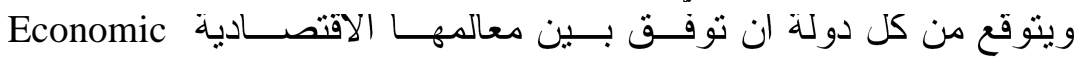
Indicators

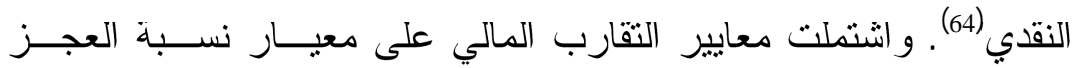
السنوي في مالية الحكومة الى الناتج المحلي الإجمالي, ومعيار نسبة الدين العام الى الناتج المحلي الإجمالي (65). وقد وجَه المجلس الاعلى لدول المجلس بضرورة الاتفاق على كيفِـــة حساب معايير التقارب النقدي و المالي, بغية التمكن من تطبيقهما بوصفئ الاعهما

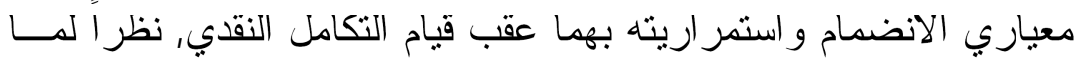
تمارسه السياسة المالية من تاثير قوي في النشاط الاقتصادي, ومن ثم في

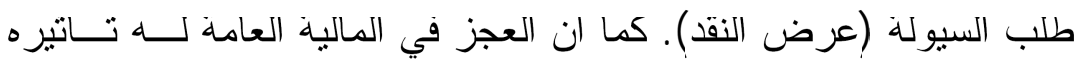

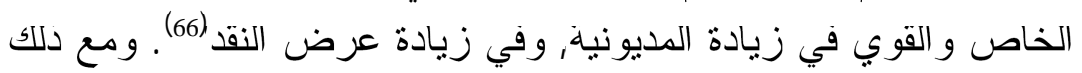

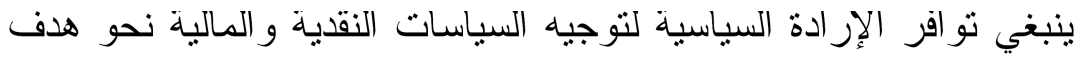
مشترك، وليس نحو اهداف وطنية صــرفة. وبـــالرغم مــن اتفــاق دول

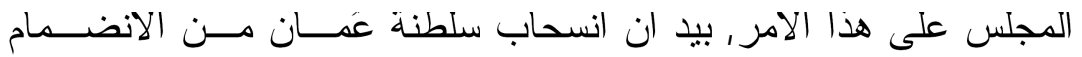

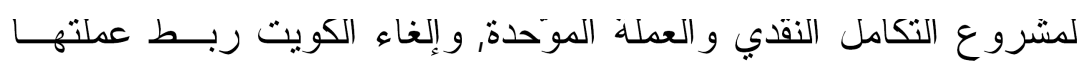

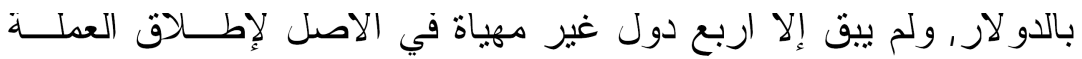

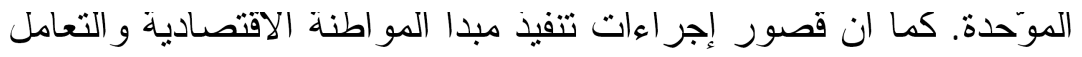

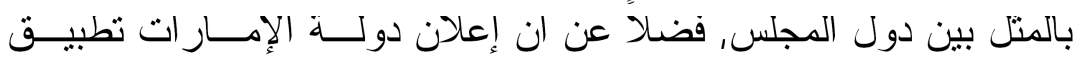
ضريبة القيمة المضافة في عام 2009, تعد و احدة من العو ائق الرئيسة امام إطلاق العملة الموّحدة, ما لم تطبق بقية الدول هذه الضريبة. إن ما تقدئدم

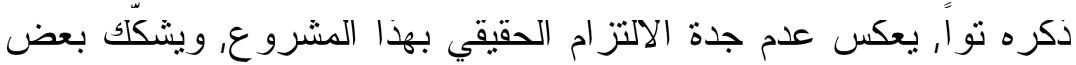

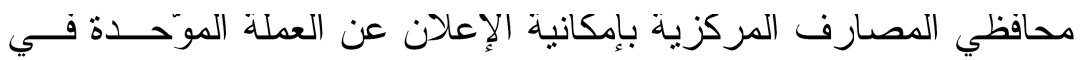




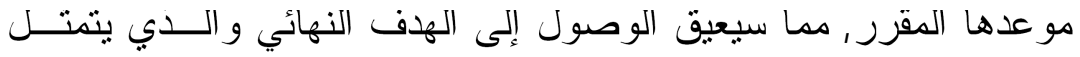
بتحقيق التكامل النقدي و إطلاق العملة الموَحدة في اليوم الاول من شـــــر كانون الثناني لعام 2010.

إن تبني دول المجلس لمشروع التكامل النقدي الــذي يتــوّج بالعملـــة الخليجية الموّحدة قد تم التخطيط له على ثلاث مر احل, إذ تم تحقيق حرية

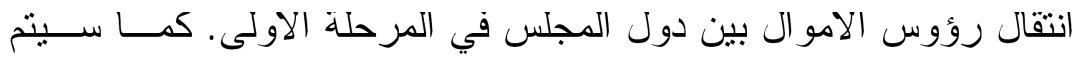
از الذ، او الحد من نكلفة الصرف بين عملات دول المجلس مع مطلع عام

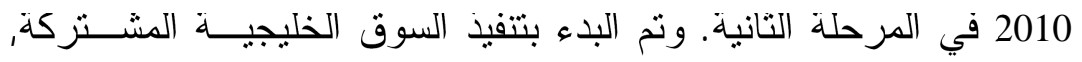
و المو اطنة الاقتصادية الكلملة, بما تتضمنه من حرية انتقال العمل, وحرية

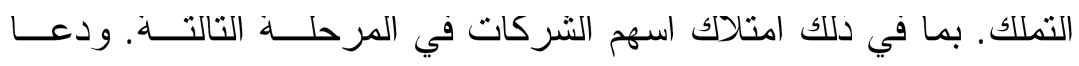
بعض المسؤولين الخليجيين الى إصلاح سياسة العملة, مسوغين دلك من

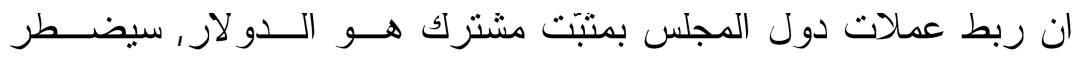

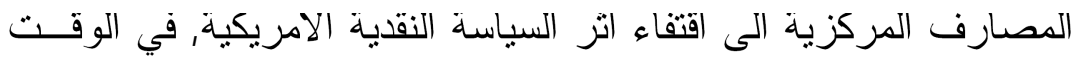

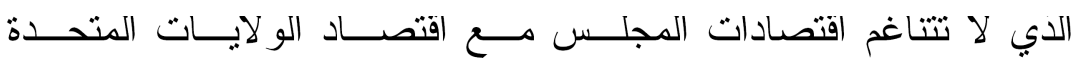
الامريكية(67). ناهيك عما تعانيه دول المجلس من معدلات عالية للتضخم

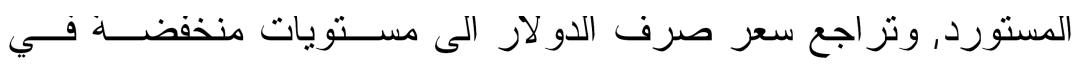
الاسواق العالمية, مما يجعل المصارف المركزية لدول المجلس عـــاجزة عن الحفاظ على ربط عملاتها بالدو لار، ومحاربة التضخم في انٍ و واحد.

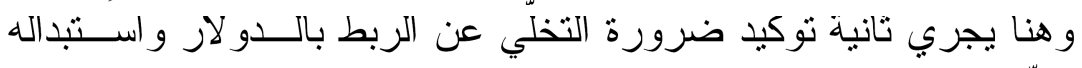

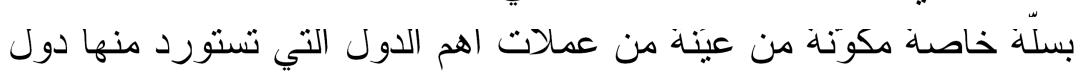

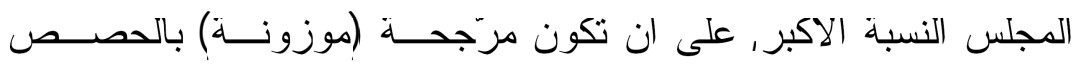
النسبية لتلكم الدول مما تستورده دول المجلس منها, وعندها ستتوحد نظم الربط, وينو افر عامل مهم من عو امل التناغم في سياسات سعر الصــرف دوف دون بين المجلس (68). 
وستبقى الإيرادات النفطية المتز ايدة الناجمة بفعل ارتفاع اسعار النفط,

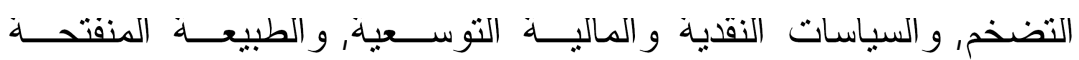

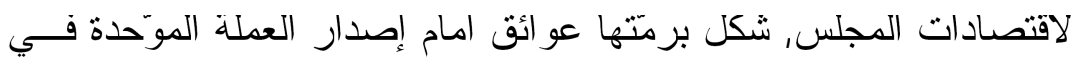

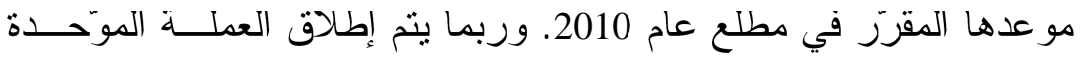
محاسبياً في المرحلة الاولى بهدف تهيئة المو اطنين لمفهوم العملة الموّحدة, كما حدث للعملة الاوروبية الموّحدة (اليورو) إبان الم ـدة (1999-2002), حتى تم إطلاقها فعلياً بوصفها عملة ملموسة, ويشير نائب الامــين العـام

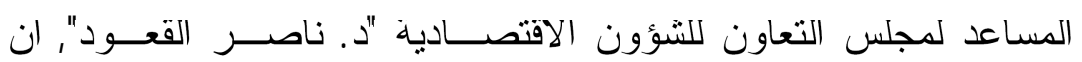

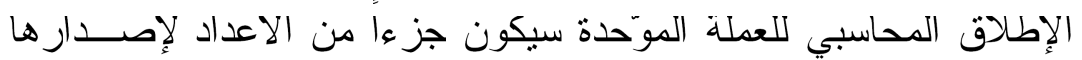

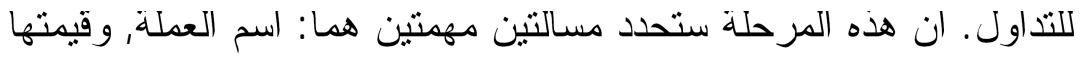
التبادلية مع المثبت المشترك, ومن ثم سيكون هناك مسمى للعملة وقيمتها

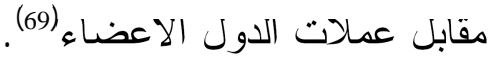

ونخلص من كل ما تقدم انفا, ان إطلاق العملة الموّحدة فــي تباشــير

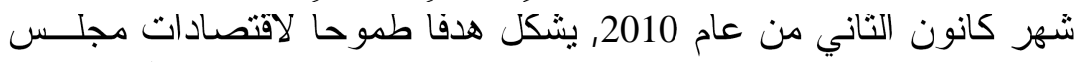

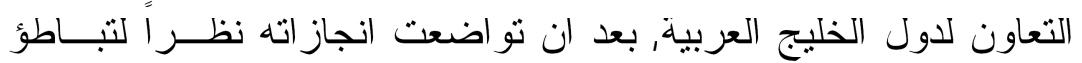

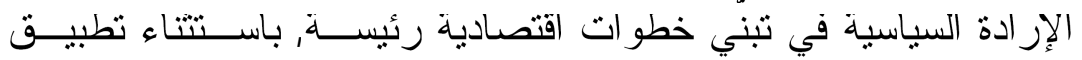
الاتحاد الكمركي في عام 003, و إنشاء السوق الخليجية المشتركة في عام 2007, و الاتحاد النقدي الدي من المؤمل قيامه في عام 2010, يد انها تبقى

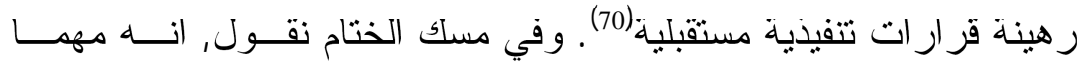

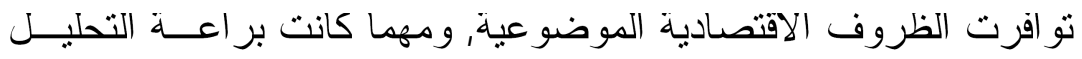

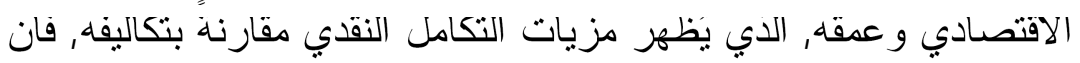
الإز ادة السياسية المؤاتية لدى حكومات دول المجلس, هي التي تقرز إقامة

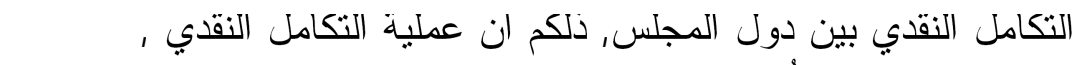
التنازل بدرجة او باخرى عن السيادة النقدية. و على هذا الاساس, ينبغ مي 
ان لا تكون الإر ادة السياسية هي مجرد استجابة للعو امل الاقتصادية البحتة

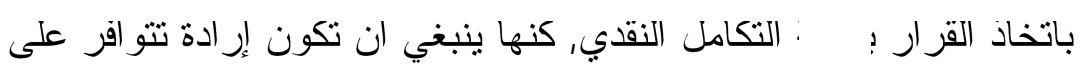

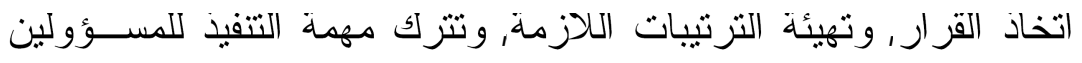

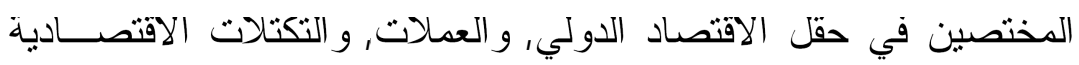
الدولية, مع قيامها بمتابعة التتفيذ وبشكل مستدام.

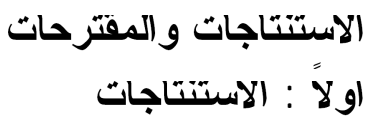

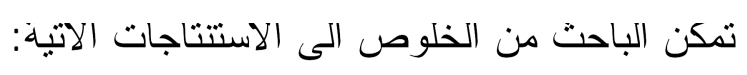

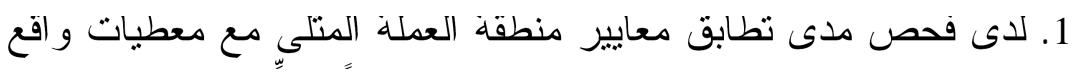

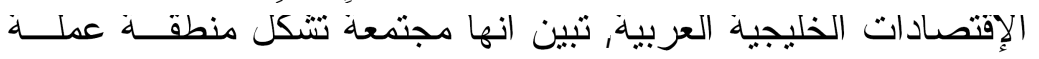

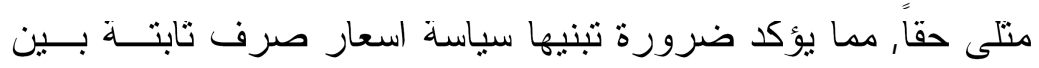

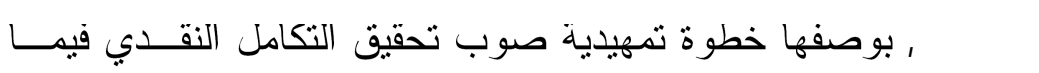

$$
\text { بينها. }
$$

2. تشير التجربة التاريخية للدول الخليجية العربية, انها لم تلجا إلى تعديل اسعار صرف عملاتها إلا نادراً, مما يعني ضآلة احتمال اســتخدامها

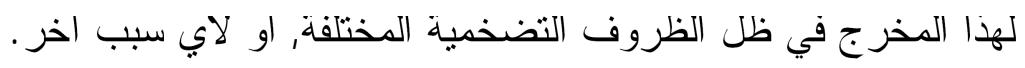

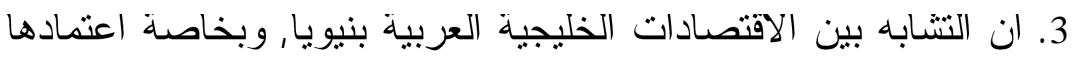

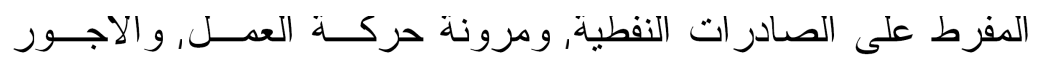

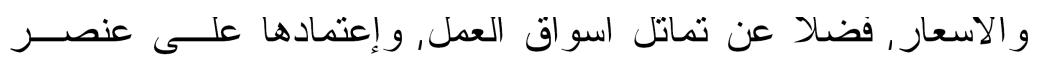

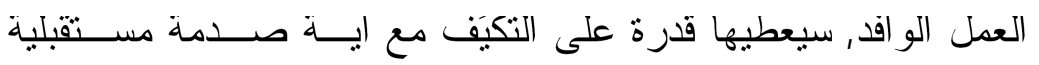
محتملة.

4. ان ضعف دور السياسة النقدية، وهيمنة الدور المالي الـــي تمارســـه

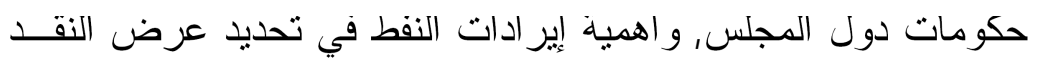


فيها, فإن ما يدعى بـــ"قفدان السيطرة على السياسة النقدية", و"التخلي عن السياسة النقدية", يصبحان عديمي الاهمبة في إطار الانضو اء تحت لو اء التكامل النقدي.

5. إن من الممكن إطلاق العملة الموَحدة بشكل تدريجي يتلازم عملها مع

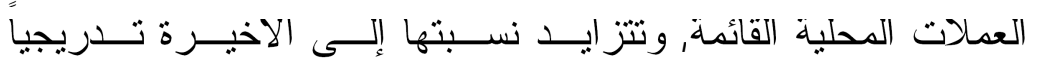

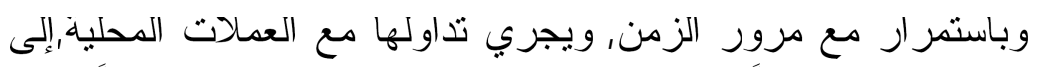

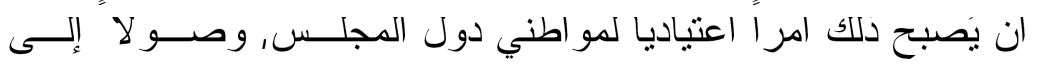
انحسار دور العملات المحلية، وتلاشي دور ها مستقبلا.

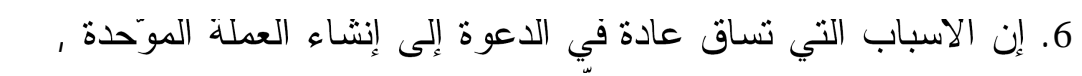

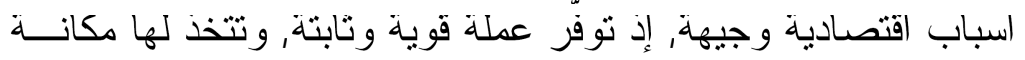

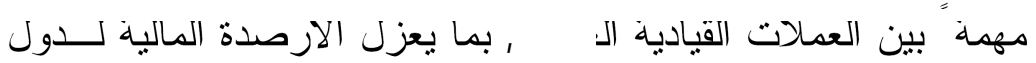
المجلس في الخارج عن إنخفاضات قيم العملات الاجنبية المعنمدة.

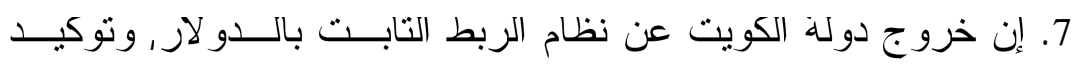

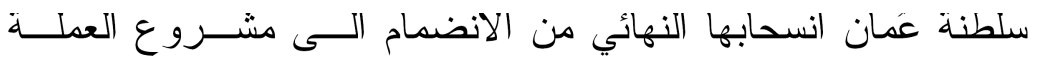
الموّحدة, يعدان من العوائق المهمة بوجه إصدار العملة الموّحدة فـي لإني مو عدها المقرر في باكورة عام دمن 2010.

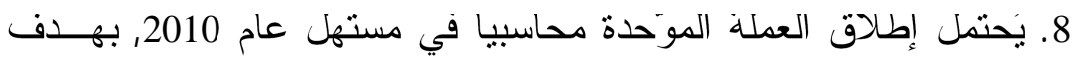

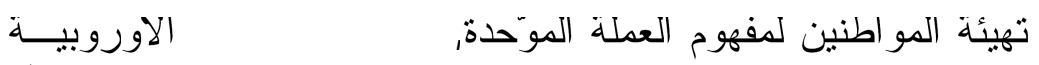

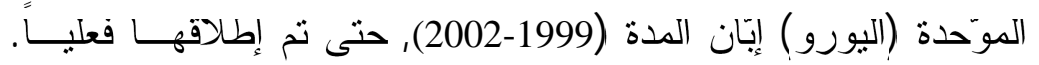

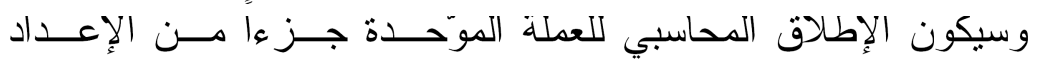
المستقبلي لإصدار ها للتداول.

تانيا: المفترحات: انتهى الباحث الى تقديم المقترحات الاتية: 
1. توكيد اهمية التخلي عن الربط بالدو لار بوصفه متبَت مشترك للعمدـــة

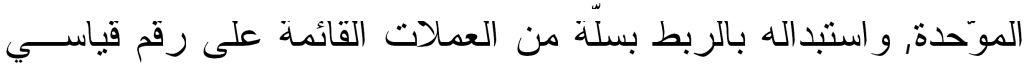

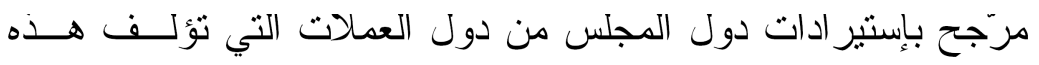
السلة, ويكون اختيار هذه العمالات واوز انها من صدلاحية دول المجلس, دول دول من دون ان تخضع لتحكم خارجي لا سلطان لها عليه.

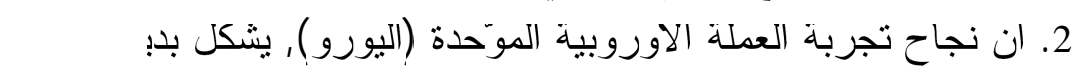

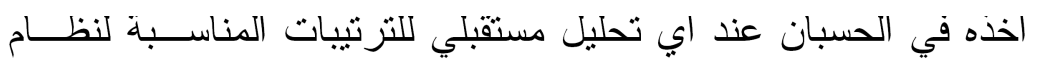
سعر صرف العملة الموّحدة القادمة لدول المجلس.

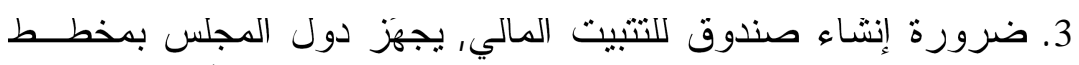
للتامين الذاتي ضد الصدمات الخارجية، وبضفي إستقر اراً على الإنفاق,

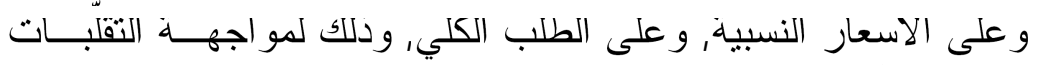

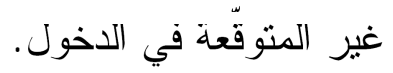

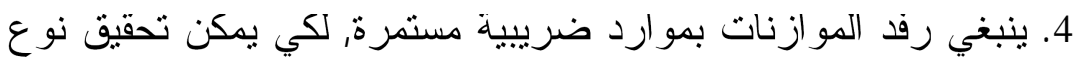

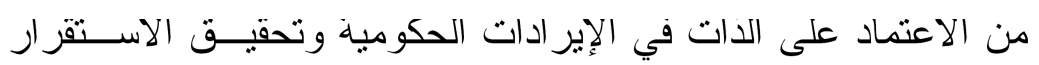
المنشود في النمو الاقتصادي بعيدا عن التاثير ات الخارجية, كما يقترح

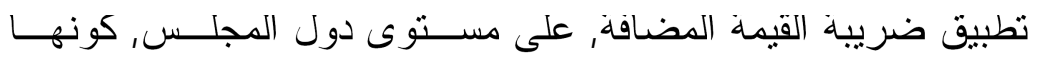
احدث الضرائب التي تقرض في الدول المتقدمة، والتي يتوقع ان يكون توزيع و عائها الضريبي اكثر عدالة و إنصافا للمساهمين فيها كافة.

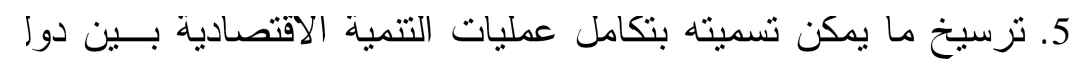
المجلس, بهدف توسيع القاعدة الإنتاجية وتتويعها, ورفع درجة استجابة لرسية العرض لتغيرات الطلب في إطار السوق الخليجية المشتركة، فض لـألا

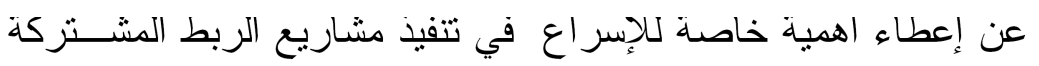

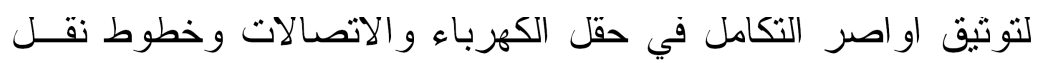
الغاز , والسكك الحديد, والطرق الدولية بين دول المجلس. 
6. التشنديد على حتمية التكامل المالي في ظل الاندماج و إنشاء عدد محدود

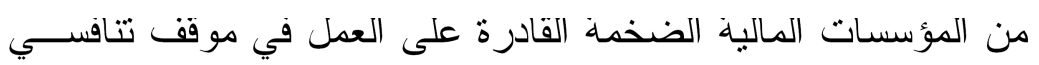
افضل, حيال التكتلات الاقتصادية و المالية و النقدية الدولية, للسيما في

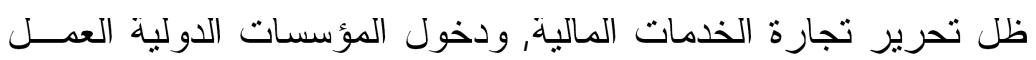
في دول المجلس بحكم اتفاقيات منظمة التجارة العالمية. 7. إعطاء اهمية خاصة لاسواق الاور اق المالية لدول المجلس، في إطار

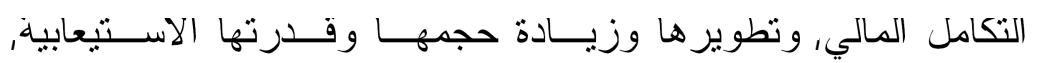

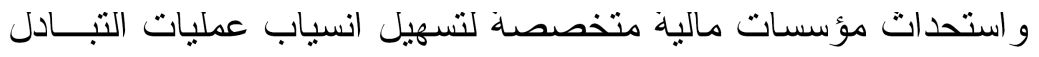
في السوق في جو من المنافسة وبخاصـــة المصـــارف الاســتـمارية، وصانعي الاسو اق, و الوسطاء. 
د. عبدالهّ فاضل الحيالي[325]

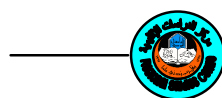

افاق التكامل النقدي: دراسة في... 
در اسات إقليمية 6 (19) [326] مركز الدراسات الإلهيبة - 


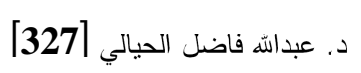

افاق التكامل النقدي: دراسة في.... - 
در اسات إقليمية 6 (19) [328] مركز الدراسات الإقليمية 


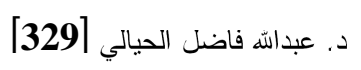

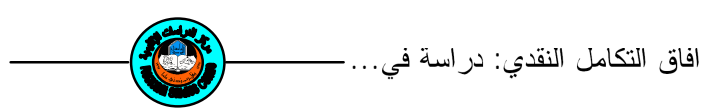

Monetary Integration Prospectives :A study in the Experience of Arab Gulf Cooperation Council countries $\left(\mathrm{GCCC}_{\mathrm{s}}\right)$

Dr. Abdullah Fadhil Al-Hayali 


\title{
Lecturer/Dept. of Economic \& \\ Social studies \\ Regional Studies Center/ University of Mosul
}

\begin{abstract}
The structural Similarity of Arab Gulf economies and the harmony of its economic, Financial and monetary Policies ,besides, as it is an optimum Currency area , that determine adopting fixed exchange rates Policy, also founding a uniform Currency has economically justifiable and notable reasons as it provide a strong and stable Currency Which Will have a status among the World leader Currencies, that will set aside financial stocks in abroad from foreign Currencies values depreciation .Moreover, affirming the significance of giving up Pegging with dollar Which is as Common anchor , and replacing it with basket of Currencies based on import-Weighted index of $\mathrm{GCCC}_{\mathrm{s}}$ from currencies, which Consists this basket .Further, Euro is an alternative to be taken into consideration of suggested Uniform Currency exchange rate system.
\end{abstract}

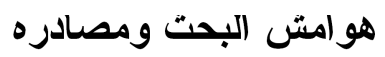


(1) Bela Balassa ,The Theory of Economic Integration, George Allen and Unwin , London ,1962.

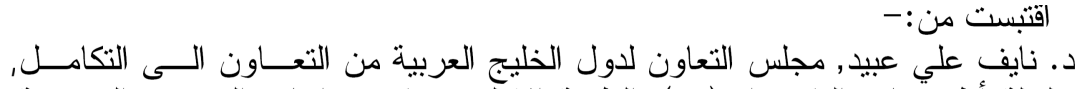

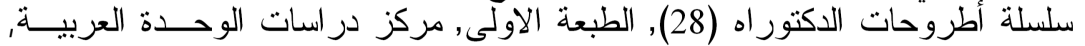

بيروت, شباط 1996, ص 28.

(2) T. Hitiris, European Community Economics ,2nd .ed. ,Simom and Schuster International Group, London,1991, PP. 122-123 .

(3) مجلس التعاون لدول الخليج العربية, الامانة العامة, الاتفاقية الاقتصـادية الموّحــدة, مقدمة الاتقاقية و الملاحق, الرياض,1981ن

(4) <<http://www.gcc-org/Archiev/chapt8.htm1〉>.

(5) فتحي محمود سكيك, "تاثير الاتحاد النقدي (على) التجارة و الاستثمار ات البينيــة",

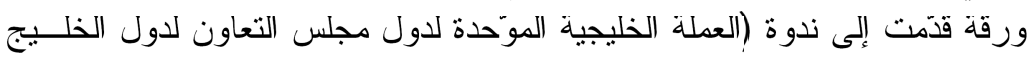

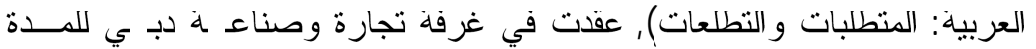

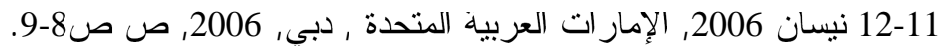

(6) جامعة الدول العربية واخرون, التقرير الاقتصادي العربي الموحد 2009, الامانـــة

العامة, القاهرة, 2009, ص الهو 19 وص 266 وصد وص 272.

(7) د. عبدالمنعم السيد علي, الاتحاد النقدي الخليجي و العملــة الخليجيــة المشــــركة,

الطبعة الاولى, مركز در اسـات الوحدة العربية, بيـروت, تنـــرين التــاني 2008,

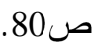

(8) Fritz Machlup, A History of Thought on Economic Integration, The Macmillan press, Columbia University, New York, 1977,P.20.

(9) Ibid. , pp. 22-23.

$$
\begin{aligned}
& \text { (10) جون وليامسون, "مفهوم وصور و اهداف التكامل النقدي", ورقــة قـدمت الــى }
\end{aligned}
$$

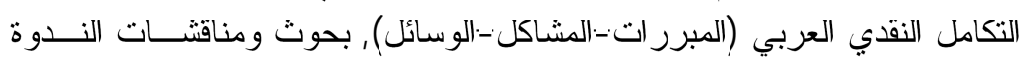

$$
\begin{aligned}
& \text { الفكرية التي نظمها مركز در اسات الوحدة العربية, الطبعة الاولى, مركز در اسات } \\
& \text { الوحدة العربية, بيروت, نيسان 1981, ص } \\
& \text { كذلك ينظر : }
\end{aligned}
$$

Peter Robson, The Economics of International Integration, Studies in Economics (17), MA: Allen and Unwin, London, Boston, 1980, pp.62-63.

$$
\text { (11) جون وليامسون, المصدر السابق, ص 43. }
$$


(12) Fritz Machlup ,op. cit., pp.125-126.

$$
\text { كذلك ينظر: جون وليامسون, المصدر السابق,ص ص 43-47. }
$$

Arthur I. Bllomfield, "The Historical Setting", Paper Presented at European Monetary Unification and its Meaning to the United States, edited by Lawrence B. Krause and walter S.Salant, Brookings Instruction, Washington Dc, 1973, pp. 31-32.

(13) Fritz Machlup, op.cit. ,P.23.

$$
\begin{aligned}
& \text { (14) د. محمد محمود الإمام, تجارب التكامل العالمية ومغز اها للتكامل العربي, الطبعة }
\end{aligned}
$$

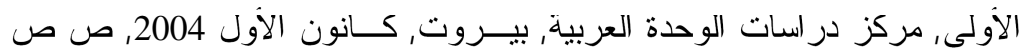

$$
\begin{aligned}
& \text {.169-168 }
\end{aligned}
$$

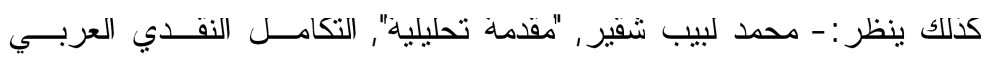

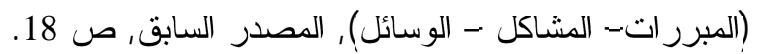

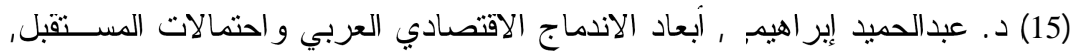

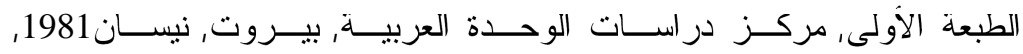

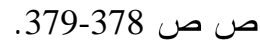

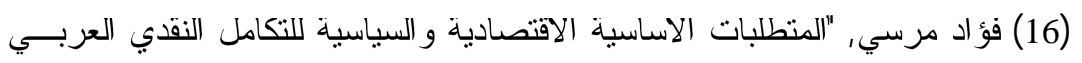

$$
\begin{aligned}
& \text { ووسائل تحقيقها", ورقة قدمت الى التكامل النقدي العربي (المبررات اتلئ - المشاكل - }
\end{aligned}
$$

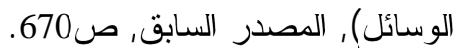

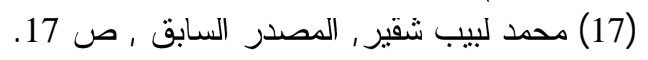

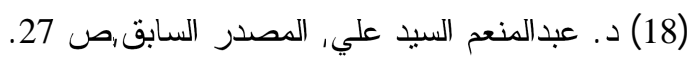

(19) -C.p.Kindleberger ,International Economics, 5th.ed., Homewood, Iee, Irwin, 1973, PP.424-432.

- H.G. Grubel, The International Monetary System, 3rd.ed., Penguin Books, Harmonds Worth ,1977,PP.109-117.

(20) Fritz Machlup , op.cit. , P.21.

(21) H.G Grubel , op.cit., P.206.

(22) Fritz Machlup, op.cit. , P.71.

(23) Robert A. Mundell, "A Theory of Optimal Currency Areas", American Economic Review, Vol.(51) ,No.(4), September1961, P.663. 
(24) R.N. Cooper (ed.), International Finance: Selected Readings, Penguin Modern Economics Readings, Harmonds Worth: Penguin Books, 1969, PP.223-234 .

$$
\begin{aligned}
& \text { (*) يعرَّ الوهم النقدي بانه سهولة تقبل الافر اد لتخفيضــات فـي دخــولهم الفعليــة }
\end{aligned}
$$

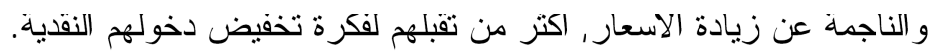

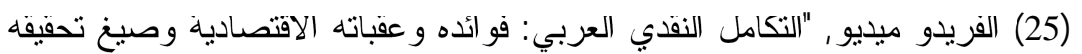

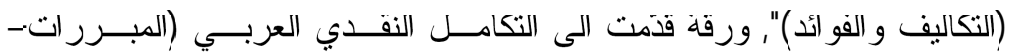

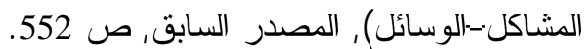

(26) John R. Presely and Geoffrey E.J. Dennis, Currency Areas, The Macmillan Press, London ,1976, P.24.

$$
\text { (27) د. عبدالمنعم السيد علي, الدصدر السابق, ص ص40. }
$$

(28) ) John R. Presely and Geoffrey E.J .Dennis ,op. cit. ,p.26.

(29) Nick Chamie ,Alain Deserves and René Lalonde, Optimum Currency Areas and Shock Asymmetry: A Comparison of Europe and the United States, Working Paper (94), Bank of Canada, Ottawa, 1994, P.1.

$$
\begin{aligned}
& \text { (30) الفريدو ميديو , المصدر السابق, ص553. }
\end{aligned}
$$

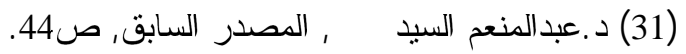

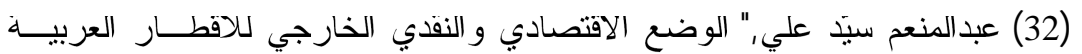

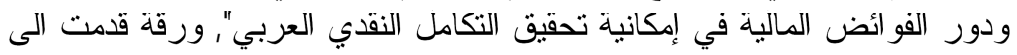

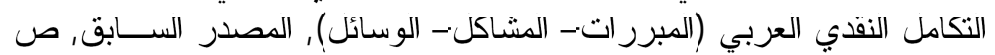

(34) H.G Grubel, OP.Cit. ,PP.212-213.

$$
\begin{aligned}
& \text { (35) د. انس بن فيصل الحجي" العملة الخليجية الموَحــدة بــين الــدينار و الــدرهم }
\end{aligned}
$$

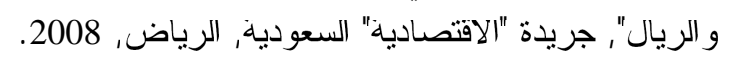

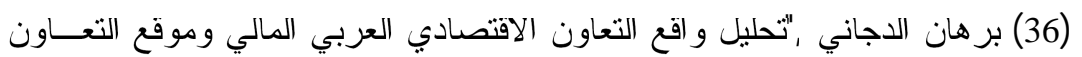

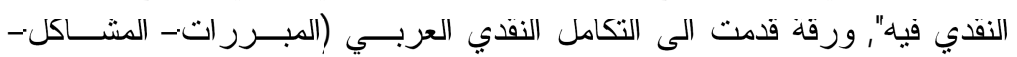

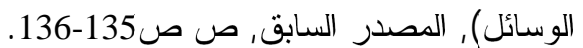

$$
\begin{aligned}
& \text { (37) د. عبدالمنعم سيّّ علي, المصدر السابق, ص488. صلئ. }
\end{aligned}
$$




$$
\begin{aligned}
& \text { (38) د. عبدالمنعم السيد علي, المصدر السابق, ص106. }
\end{aligned}
$$

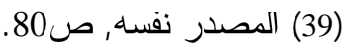

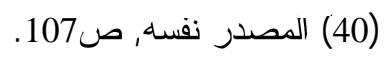

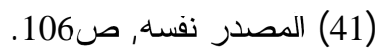

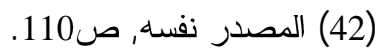

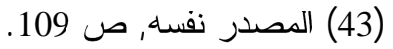

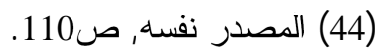

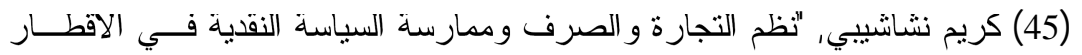

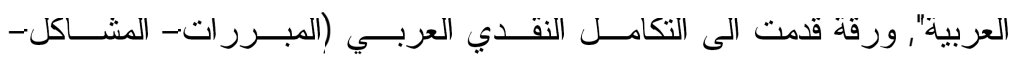

$$
\begin{aligned}
& \text { الوسائل), المصدر السابق, ص193. }
\end{aligned}
$$

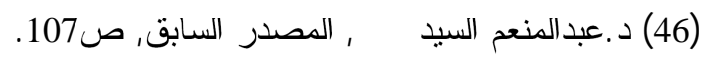

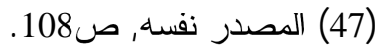

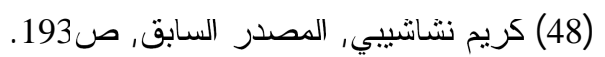

$$
\begin{aligned}
& \text { (49) د.عبدالمنعم السيد علي, المصدر السابق, ص108) }
\end{aligned}
$$

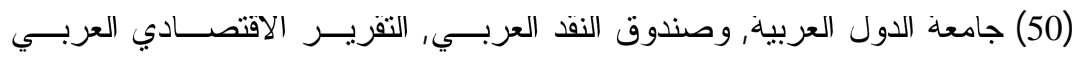

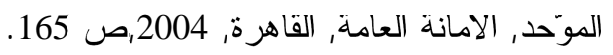

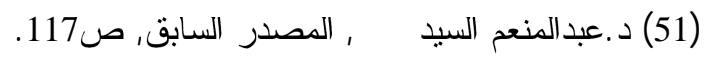

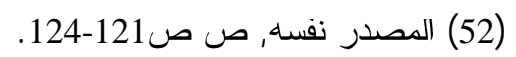

$$
\begin{aligned}
& \text { (*) وهو عبارة عن المتوسط الحسابي لاسعار صرف صاف العملة المعنية لدولة ما مقابــل }
\end{aligned}
$$

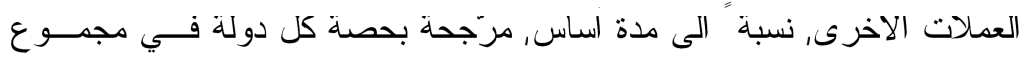

$$
\begin{aligned}
& \text { استير ادات الدولة المعنية. } \\
& \text { ينظر : }
\end{aligned}
$$

A. B.Crocket and Saleh M. Nsouli, "Exchange Rate Policies For Developing Countries", Journal of Development Studies, Vol.(13), No.(2), January 1977, P.650.

$$
\begin{aligned}
& \text { (53) د. عبدالمنعم السيد علي, المصدر السابق, ص } 130 .
\end{aligned}
$$

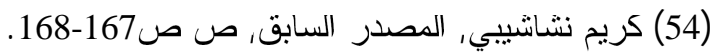

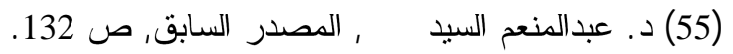

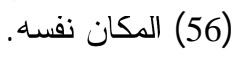

(57) A.B. Crocket and Saleh M. Nsouli, OP.Cit. P.848.

(58) Loc. Cit. 


$$
\begin{aligned}
& \text { (50) د. عبدالمنعم السيد علي, المصدر السابق, ص } 133 .
\end{aligned}
$$

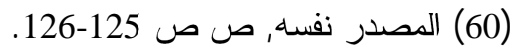

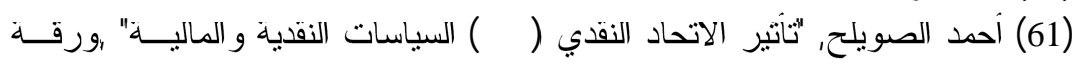

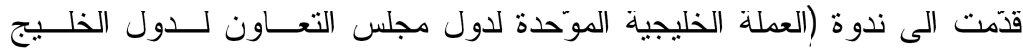

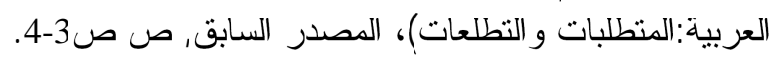

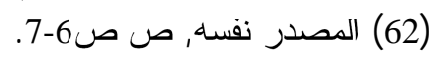

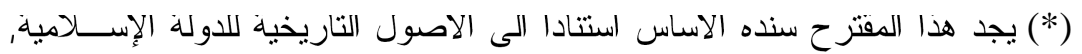

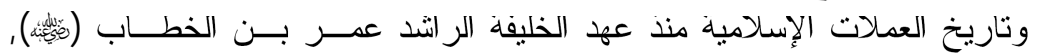

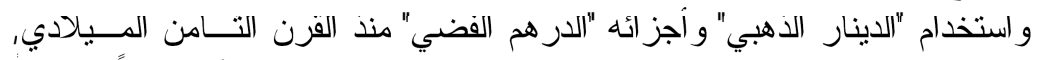

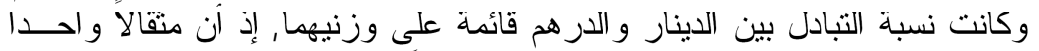

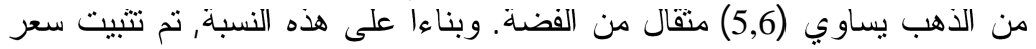

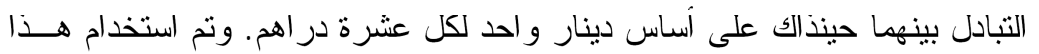
المعيار لمدة طويلة من الزمن. و هذا ما انتهت إليه خطة العملة الخليجية المقترحة،

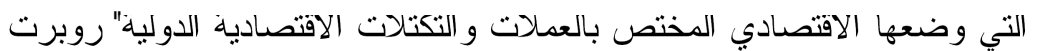

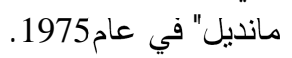

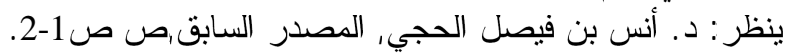
(63) أحمد الصويلح, المصدر السابق,ص فيصل 4.

$$
\text { (65) المصدر نفسد, صساه, ص } 6 .
$$$$
\text { (66) (65) المكان نفسه. }
$$

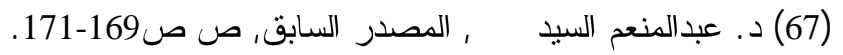

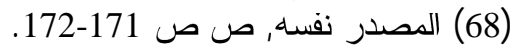

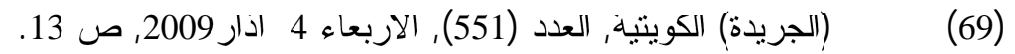

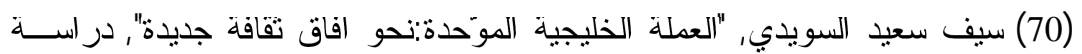

$<<$ http://www.s.alsowaidi@qu.edu.qa >>.

$$
\text { منشورة على الر ابط الاتي: - مئل }
$$


در اسات إقليمية 6 (19) [336] مركز الدراسات الإقليمية

\author{
الملحق الاحصائي \\ المعالم الرئيسه للمتفيرات الاوتصاديه في دول مجلس التعاون لدول \\ الخليج العربيه لعام2008
}

(1) الملحق (1)

\begin{tabular}{|c|c|c|c|c|c|c|c|c|c|c|c|c|c|c|}
\hline النفط الد الد & الغاز الطبيعي & (الغاز الطبيعي & (النقطيطي & 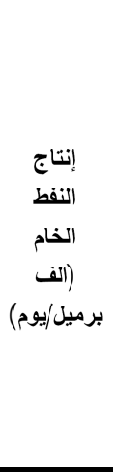 & 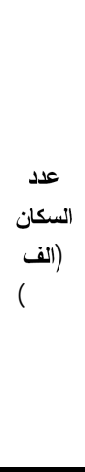 & النض النضخم & $\begin{array}{l}\text { النمو\% } \\
2007- \\
2008\end{array}$ & 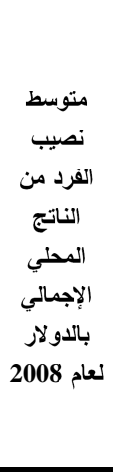 & 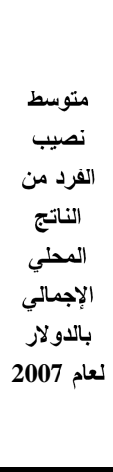 & 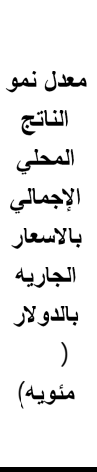 & 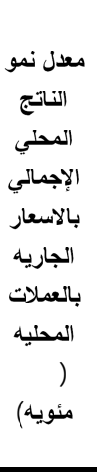 & الالإلمالي & 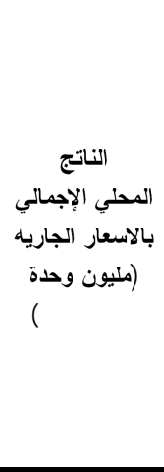 & دوله \\
\hline 0.635 & 49.200 & $6,072.0$ & 97.80 & $2,630.3$ & 4,765 & 11.5 & 21.9 & 70651 & 57946 & 27.4 & 27.4 & 250,517 & $\begin{array}{c}920,023.4 \\
\text { درهم }\end{array}$ & 'مارات \\
\hline .895 & 11.500 & 91.0 & 0.12 & 182.2 & 1,123 & 3.5 & 20.0 & 52574 & 43815 & 31.9 & 31.9 & 24,388 & $\begin{array}{c}\text { 9,151.2 } \\
\text { دينار }\end{array}$ & جرين \\
\hline 7.097 & 79.500 & 7,305.0 & 264.25 & 9,317.8 & 24,807 & 9.9 & 25.0 & 43046 & 34431 & 22.1 & 22.1 & 468,800 & $\begin{array}{c}1,758,001.0 \\
\text { ريال }\end{array}$ & معوديه \\
\hline 3.296 & 25.179 & 950.0 & 5.50 & 748.3 & 2,867 & 12.4 & 22.0 & 21668 & 17754 & 44.0 & 44.0 & $\mathbf{5 9 , 9 4 5}$ & $\begin{array}{c}23,049.0 \\
\text { ريار }\end{array}$ & عمان \\
\hline 7.428 & 59.800 & $25,172.0$ & 15.2 & 854.3 & 1,448 & 15.0 & 37.7 & 20898 & 15180 & 44.0 & 44.0 & 102,303 & $\begin{array}{c}\text { 372,384.0 } \\
\text { ريال }\end{array}$ & قطر \\
\hline 7.690 & 12.600 & 1.780 .0 & 101.50 & $2,680.0$ & 3,442 & 10.6 & 19.3 & 18898 & 15835 & 29.3 & 22.1 & 148,168 & دينار & كويت \\
\hline
\end{tabular}

المصدر - جامعه الدول العربيه واخرون, التقريز الافتصادي العربي الموحد 2009, الامانه العامه,

القاهزة, 2009, صفحات منفرفه. 
(الملحق(2)

\begin{tabular}{|c|c|c|c|c|c|c|c|c|c|c|}
\hline \multicolumn{3}{|c|}{ التغير السنوي في العوامل المؤُثرة في التغير في السيوله } & \multicolumn{2}{|c|}{ مكونات السيوله ا المحليه } & \multirow{2}{*}{ المحل النيوله } & \multirow{2}{*}{ 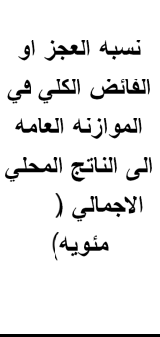 } & \multirow{2}{*}{ 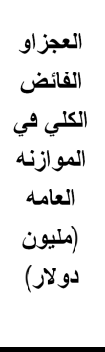 } & \multirow{2}{*}{ العام الى الناتج } & \multirow{2}{*}{ الافقاق العام } & \multirow{2}{*}{ الدوله } \\
\hline صافي البنود & صافي الإتثمان & الموجودات & شبه النقود & النقود & & & & & & \\
\hline 24.49 & 48.45 & 79.36- & 69.55 & 30.45 & 19.20 & 6.0 & 15.094 & 20.8 & 52.014 & الامارات \\
\hline 22.07- & 40.90 & 27.34- & 71.78 & 28.22 & 18.40 & 6.7 & 1.642 & 22.5 & 5.480 & البحرين \\
\hline 8.22 & 132.71- & 43.80 & 54.20 & 45.80 & 17.65 & 33.0 & 154.913 & 29.6 & 138.685 & السعوديه \\
\hline 18.49 & 28.78 & 11.84 & 73.54 & 26.46 & 23.06 & 0.3 & 204 & 32.8 & 19.663 & عمان \\
\hline 48.94 & 56.42 & 20.47 & 69.18 & 30.82 & 19.78 & 9.6 & 9.831 & 24.1 & 24.608 & هطر \\
\hline 11.25 & 9.48 & 32.61 & 80.09 & 19.91 & 15.77 & 22.5 & 33.300 & 23.4 & 34.63 & الكويت \\
\hline
\end{tabular}

المصدر: - جامعه الدول العربيه واخرون، التقرير الاقتصادي العربي الموحد

2009, الامانه العامه, القاهرة, 2009, صفحات منفرفه. 
(3) (3لحق

\begin{tabular}{|c|c|c|c|c|c|c|c|}
\hline \multirow{3}{*}{ المو ازلى الناتج الجاريد } & \multirow{3}{*}{ 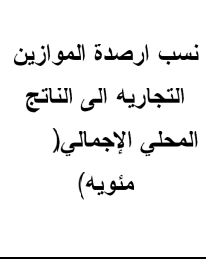 } & \multirow{3}{*}{ 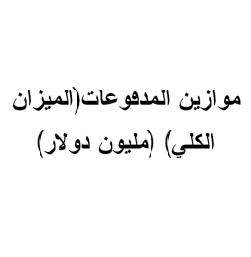 } & \multicolumn{4}{|c|}{ مساهمه العو (مل المؤئرة في الثغير في السيوله المحليه(نسببه مئوية) } & \multirow{3}{*}{ الدوله } \\
\hline & & & \multirow{2}{*}{ الاخئ } & \multicolumn{2}{|c|}{ صافي الاتتمان المحلي } & \multirow{2}{*}{ الموجودات } & \\
\hline & & & & 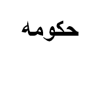 & 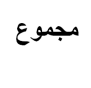 & & \\
\hline 6.9 & 23.2 & 46,943.5- & 7.1- & $4.2-$ & 48.8 & 22.5- & الإمارات \\
\hline 9.3 & 13.3 & 294.1- & 7.7 & 4.6- & 28.5 & 17.8- & 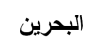 \\
\hline 28.6 & 45.2 & $147,800.0$ & $6.5-$ & $60.0-$ & 40.8- & 64.9 & السعودية \\
\hline 9.1 & 28.4 & $1,825.7$ & 9.1- & 20.5- & 24.6 & 13.6 & 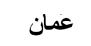 \\
\hline 12.7 & 27.8 & $11,926.4$ & $23.0-$ & 9.8 & 53.5 & 20.9 & صطر \\
\hline 43.7 & 43.2 & 639.0 & $4.3-$ & 8.8- & 9.8 & 14.7 & الكويت \\
\hline
\end{tabular}

المصدر : - جامعه الدول العربيه واخرون, التقرير الافتصادي العربي

الموحد 2009, الاماته العامه, القاهرة, 2009, صفحات متقرفه. 


$$
\text { د. عبداله فاضل الحيالي[339] }
$$

(4) الملحق (4)

\begin{tabular}{|c|c|c|c|c|c|c|c|}
\hline \multirow{2}{*}{ نسبة إجمالي الاين العام الخارجي } & \multirow{2}{*}{ إلجمالي خلمه الآلين } & \multirow{2}{*}{ إجمالي الاين العام الخارجي القائم وي } & \multirow{2}{*}{ تلغطيه الاحتياطات } & \multirow{2}{*}{ الاحنياطيات الخارجيه (مليونتئناء الذهب) } & \multicolumn{2}{|c|}{ الثرصيل القائم لإجمالي } & \multirow{2}{*}{ للدوله } \\
\hline & & & & & 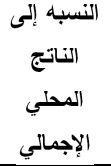 & الريائم & \\
\hline$\cdots$ & $\ldots$. & $\cdots$ & 2.1 & $31,694.5$ & $\cdots$ & $\cdots$ & الإمارات \\
\hline$\cdots$. & $\cdots \cdot$ & $\cdots$ & 3.3 & $3,937.2$ & $\ldots$. & $\ldots$. & البحرين \\
\hline$\cdots$. & $\cdots \cdot$ & $\cdots$ & 3.6 & $30,342.0$ & $\cdots \cdot$ & $\cdots \cdot$ & السعوديه \\
\hline 11.5 & 608.0 & $6,879.0$ & 6.6 & $11,445.5$ & .... & ..... & عمان \\
\hline$\ldots$. & $\ldots$. & $\ldots$. & 4.8 & $9,489.3$ & .... & ..... & هطر \\
\hline .... & $\ldots$ & $\ldots$ & 8.9 & 17,112.6 & 5.2 & 7.720 & الكويت \\
\hline
\end{tabular}

الموحد 2009, الاماته العامه, القاهرة, 2009, صفحات متفرهه. 
در اسات إقليمية 6 (19) [340] مركز الدراسات الإقليمية

(5) الملحق (5)

\begin{tabular}{|c|c|c|c|c|c|c|c|c|}
\hline \multirow[t]{2}{*}{ التغير النعار الفنوي } & \multicolumn{2}{|c|}{ حقوق السحب الخاصدأمنتوسط المدة) } & \multicolumn{2}{|c|}{ الععله الاوروبيه الموحدة (اليوردات العملات مقابل } & \multicolumn{3}{|c|}{ اسعار صرف وحدات العملات مقابل الدولار } & \multirow[t]{2}{*}{ الدوله } \\
\hline & 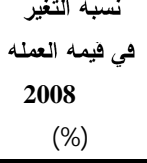 & 2008 & 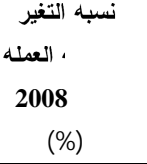 & 2008 & 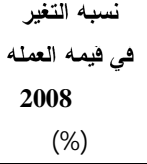 & 2008 & العمله المحليه & \\
\hline 6.1 & 3.35 & 5.8029 & 6.77 & 5.4015 & 0.00 & 3.6725 & درهم & الامارات \\
\hline $6.7-$ & 3.35 & 0.5941 & 6.61 & 0.5541 & 0.00 & 0.3760 & دينار & البحرين \\
\hline 2.3 & 3.35 & 5.9254 & 6.66 & 5.5105 & 0.00 & 3.7500 & ريال & السعوديه \\
\hline 1.1 & 3.35 & 0.6075 & 6.62 & 0.5661 & 0.00 & 0.3845 & ريال & عمان \\
\hline 1.2- & 3.35 & 5.7516 & 5.3521 & 5.5521 & 0.00 & 3.6400 & ريال & فطر \\
\hline 7.2 & 2.20- & 0.4248 & 1.85 & 0.3964 & 5.57- & 0.2685 & دينار & الكويت \\
\hline
\end{tabular}

المصدر: - جامعه الدول العربيه واخرون, التقرير الافتصادي العربي

الموحد 2009, الاماته العامه, القاهرة, 2009, صفحات متقرفه. 


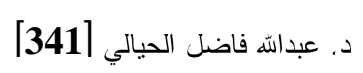

افاق النكامل النقدي: دراسة في.... - 